\title{
歩行訓練器のための疑似歩行動作一回転運動変換機構の設計
}

南後 淳*1, 前田 和則 ${ }^{* 2}$, 加藤 良祐 ${ }^{* 3}$, 横澤 恵輔*4, 佐藤 拓也 ${ }^{* 5}$

\section{Design of simulated walking motion - rotational motion transformer for a walker}

\author{
Jun NANGO ${ }^{* 1}$, Kazunori MAEDA ${ }^{* 2}$, Ryousuke KATOU*3 ${ }^{* 3}$ Keisuke YOKOZAWA ${ }^{* 4}$ \\ and Takuya SATO ${ }^{* 5}$
}

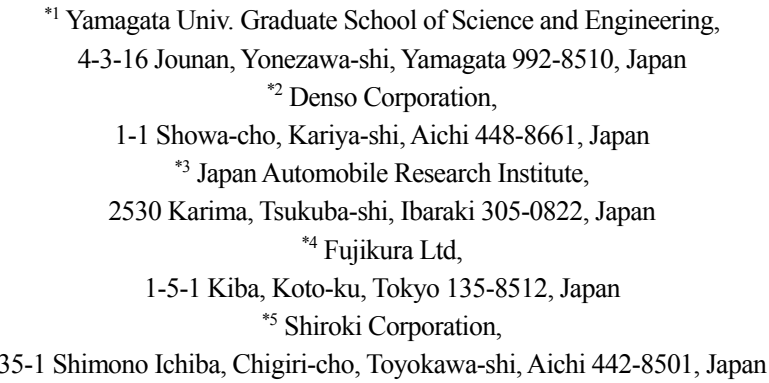

Received 27 June 2014

\begin{abstract}
In general rehabilitation, the walking stick, parallel bars, and walker are used as walking training devices. Users of these devices bear their weight with the hands or legs, and doing so is painful in some cases. In recent years, population aging has progressed rapidly and a labor shortage in the welfare field has become a serious problem. Against this background, it is necessary to develop a walking training device that can motivate patients to train without assistance from a care worker. In this research, we designed and developed a walker equipped with an assist mechanism that translates simulated walking motion into rotational wheel motion. Using the walker, the patient is supported by a saddle, so the hands and legs are relieved of pain due to supporting body weight. The motion transformer is designed using a planar 6-link mechanism, which transforms oscillating motion to rotational motion. Joint angular displacements were measured with a wearable device. Results showed that general walking trajectories can be obtained. This mechanism is designed such that the pedal follows the foot motion in walking by comparing the coupler curve of the mechanism with the trajectory of an ankle joint in a walking motion. We manufactured four types of walkers for testing. Type I uses a motion transformer consisting of only revolute pairs. Type II uses a motion transformer consisting of revolute pairs and a prismatic pair (sliding joint). Type II-ankle free uses a Type II motion transformer from which two links were removed in order to allow free rotational motion of the ankle joint. Lastly, the Type III walker has an axle in the front in order to facilitate riding from the rear and to allow free rotational motion of the ankle joint. Pedaling force was measured and compared among the four types. It was found that free ankle joint movement was effective in decreasing the pedaling force. The results indicate that the motion transformer could be driven with a small force and with a simulated walking motion as the input. However, the angle between the direction of foot velocity and the direction of pedaling force was approximately $\pi / 2$, and so driving the device using a pedaling motion could produce a sensation different from that of a normal walking motion. Eliminating discomfort during operation is left as a
\end{abstract}

\footnotetext{
No.14-00345 [DOI:10.1299/transjsme.2014trans0344]

*1 正員, 山形大学大学院理工学研究科 (下992-8510 山形県米沢市城南 4-3-16)

*2 山形大学大学院理工学研究科 (現 (株)デンソー (†448-8661 愛知県刚谷市昭和町 1-1))

*3 山形大学大学院理工学研究科 (現 (一財) 日本自動車研究所 (†305-0822 茨城県つくば市苅間 2530)

*4 山形大学大学院理工学研究科 (現 フジクラ電装 (株) (†135-8512 東京都江東区木場 1-5-1))

*5 山形大学大学院理工学研究科（現 シロキ工業 (株)（†442-8501 愛知県豊川市千両町下野市場 35-1) )

E-mail of corresponding author: nango@yz.yamagata-u.ac.jp
} 
future task.

Key words : Planar mechanism, Pattern maching method, Assistance device

\section{1. 緒}

歩行機能を回復寸るためのリハビリテーションでは，杖，平行棒など体重を腕や筋力の低下した脚部で支えな ければならず，リハビリの初期段階では負荷が大きいために苦痛を伴う場合も少なくない.

一方，自転車はこのような場合，脚部の機能回復に効果が期待できるとともに移動手段としても用いることが できる．ところが自転車を漕ぐ動作は，歩行動作に比べ膝関節など関節可動域が小さく大腿部を大きく上げる動 作は歩行訓練を目的とするときには負担も大きく上半身（上体）も不安定になり，転倒などの危険もある.

免荷した歩行訓練器としてはベルト等により使用者を上部から支持する装置(トレッドミル ロボウオーク・エ キスパンダー，インターリ八（株）社製，2013)が開発されており，また転倒防止のためのブレーキ装置について も報告されている(Kai, 2011)。これらはトレッドミル上での歩行訓練であり，モチベーションを高めるために映 像による移動の疑似体験のできる装置の開発( 2 ベルト歩行訓練機 PW-10，（株）日立製作所，2013)も行われてい る.

移動できる装置としてはトレッドミル上での歩行の移動距離を拡大し,少ない歩数でより移動できる形式(中島 他，2012）もある. また，別の形式として，人体に装着する形式の動作支援の開発がそのアクチュエータとともに 進められていることが報告されている(佐藤他，2012，赤木他，2011，稲葉，則次，2011）。歩行補助を目的とし た装置においても負荷等を調整した訓練が可能となり, 神経回路の修復への効果も期待できる報告がされている (新宮他, 2010). また, 歩行の補助もしくは移動の支援を行う装置が開発されており (池原他, 2011, 山田, 森田, 2013，田中他，2011a，2011b，Wu, et al., 2007, 安藤他，2012, Tanaka, et al., 2013)，Q0L の改善に向けた機器選定に ついても報告がされている，一方，ロボット技術を応用したリハビリ装置の開発(裴他，2012，安藤他，2011，裴 他，2011，Zhu，et al., 2012，林知広他，2011)やリハビリ効果を定量的に評価する装置の開発(林良太他，2012，柳 原他，2011）も進められている. しかし，これらの装置では，複数のアクチュエータとそれを駆動するドライバを 要し，システムとして複雑になる傾向があり，使用者が直観的に操作することは困難である．また，高性能が期 待される一方, 高価となり，一般ユーザが手軽に使用できる状況にない. また, 筋電位を使用する場合 (Gopura and Kiguchi, 2008)は, 事前の処理も必要になる. コントローラにはその安全性も十分配慮しなければならない(原他, 2012).

そこで本研究では，自転車と同様サドルで脚部を支持する体重を免荷した状態で疑似的に行う歩行動作を車輪 の回転運動に変換する機構（疑似歩行動作一回転運動変換機構）を備えることで手軽に取組むことが容易な歩行 訓練器の開発を行う．歩行訓練に取り組み始めた車い寸使用者が移動手段として用いることができるとともに疑 似的な体験ではなく, 実際に歩行動作を入力とした移動を行うことでその意義を再確認し, リハビリテーション の動機付けとして期待できる. 歩行に必要な関節可動域を確保するとともに脚部の残存機能を活用するので負荷 を調整することで筋力回復の効果も期待できる.

上記の歩行訓練器を開発するために, モータなどの外部動力を必要としない形式とし，全体を簡易なシステム で構築する. そのことで, 操作時の安全性の確保が容易で, 使用者自身が自らの判断でより直観的に操作できる 歩行訓練器の実現を目指寸.あたかも歩くがごとく, 立位の姿勢を維持しながら日常的に使用寸る訓練器であり， 使用者の訓練への自発的な取り組みを促し，リハビリテーションの現場での人手不足への効果を期待するもので ある．そのためには，車輪を駆動するために入力動作が歩行動作を疑似的に再現し，かつペダルでの駆動のため の操作が，立脚や遊脚などの歩行位相の感覚を与えるものでなければならない.

そこで，疑似歩行動作一回転運動変換機構を設計するために，歩行動作をある特定の時間間隔で計測し，歩行 1 サイクルを，運動変換機構のクランク 1 回転で再現する手法を提案する.

一般に，機構を用いてある特定の運動から回転運動を得て移動のための出力運動とするためには，出力軸まわ りに装置の移動に必要なトルクを伴わなければならず，運動伝達性が良好な機構を用いなければ，使用者にとっ て負担となる. 
異なる平面リンク機構を用いて疑似歩行動作を回転運動に変換する装置を 4 種類設計し, 歩行訓練器の試作を 行う. 装置使用時の脚部関節可動域を測定し, 脚部姿勢や関節可動域の大きさや, ペダル踏力を測定することで 必要な駆動力を使用者への負担として評価し，比較する.

装置を試作し，上記の各項目で評価することにより，出力の回転運動を得るための，疑似的な歩行動作が入力 運動として用いられていることを示寸とともに, 移動に必要な出力トルクが使用者に過度な負担を強いることな く得られていることを示す. また, 脚部姿勢や踏力の測定結果から, 歩行位相の感覚の再現が使用者に提示でき ているかについて考察する.

\section{2. 疑似歩行動作 - 回転運動変換機構}

サドルで免荷した状態で行う歩行動作を回転運動に変換する装置（疑似歩行動作 - 回転運動変換機構）を用い た歩行訓練器の概観を図 1 に示寸. また, 図 2 6 には, 平面リンク機構を用いて, 疑似歩行動作 - 回転運動変換 機構を設計するための機構図を示す．歩行動作における脚部運動を矢状面と平行な平面内で表現し, 各関節の回 転軸はすべて平行であるとする.

出力とする回転運動を得るのに必要な摇動運動を与えるとき, 図 1 に示寸ように, 中間節の描く曲線 (中間節, カップラーカーブ） が歩行動作を行う人体脚部の足関節の描く軌跡と一致するよう平面 4 節リンク機構の機構定 数を決定している. 図 2，3，5および 6 では，Link 4 および Link 5 が，図 4 ではLink 6 およびLink 7 が，それ ぞれ人体の大腿部および下腿部を表す。これらの運動変換機構に脚部を表す 2 つのリンクを追加することで脚部 関節の角運動をシミュレーションしながら設計することができる.

さらに, 図 3 および 4 では, 足裏を案内するために 2 つのリンクを追加し, 歩行動作を行う足部の運動を再現し ている. ただし, 図 3 の機構では, 装置全体が大型化し, 占有空間が大きくなることから図 4,5 および 6 に示寸 ようにスライダを用いた装置についても設計している.この対偶の変更は, 図 3 の Link 1 を図 4 での Link 3 に 置き換えることで実現している.

このように, 図3では, 運動変換機構は, 寸べて回転対偶で構成されているのに対し, 図 4 6では, スライダ を用いて占有空間の縮小を図っている, また, 図 3 では, Link 7 に, 図 4 では, Link 5 に足部を置くペダルとし て, 足部の運動を案内寸る機構となっているのに対し，図 5 および 6 では, ペダルは表示しておらず, 足関節の 回転運動は，運動変換機構において拘束されていない.

また, 図 3〜5では, クランクは, 人体後方に位置しているのに対し，図6では，人体前方に位置している.
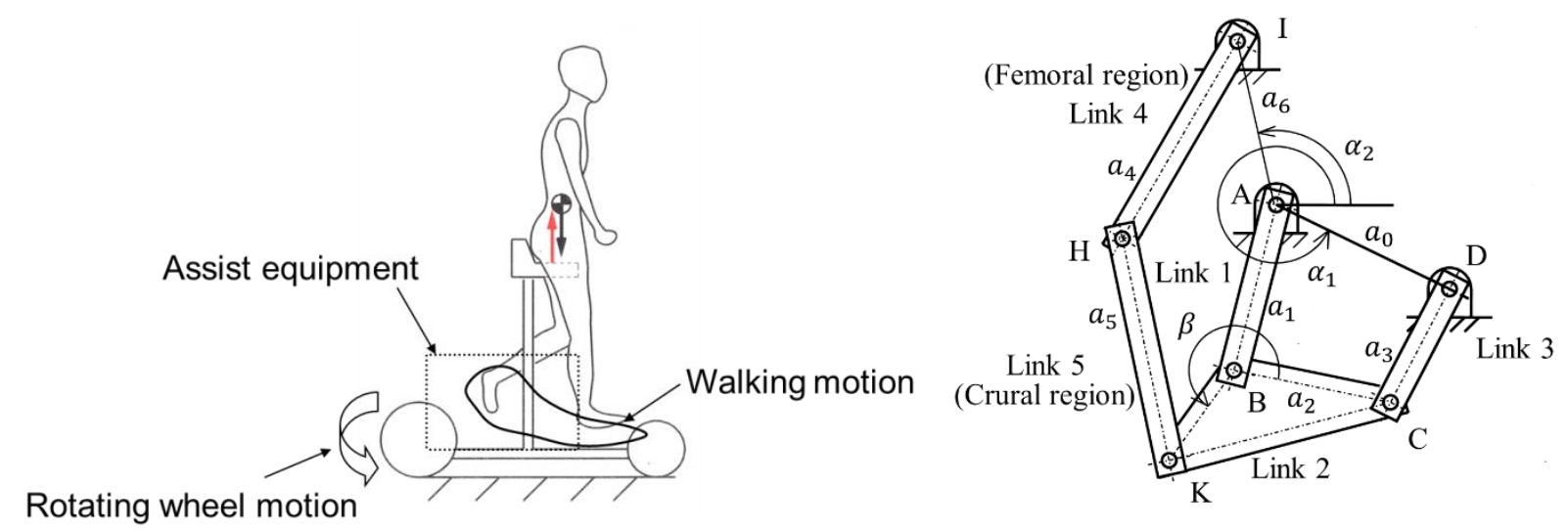

Fig. 1 The motion transformer equipped on the walker. This device drives the wheel when the user inputs a simulated walking motion. The device assists users' walking motion.

Fig. 2 The kinematic model of the motion transformer consisted with a planar four-bar linkage. The kinematic model is combined with two links indicating a human leg to obtain the proper kinematic constants. The device should be designed to make the point $\mathrm{K}$ follow the trajectory of the ankle joint in the walking motion. 
便宜上，本報では，運動変換機構を構成する機構が，図 3 の回転軸のみで構成された平面 6 節リンク機構の場 合を I 形，図 4 のスライダを含む平面 6 節リンク機構の場合を II 形，図 6 のスライダ・クランク機構の場合を III 形と呼称する.

また，図 5 は，基本構造および寸法は II 形と同じであることから II（足部拘束なし）形とする.

これらの運動変換機構の寸法決定は, 運動学モデルを用い, 下腿部を模したリンクを装置に連結する回転対偶 の描く軌跡が，歩行時に足関節の描く軌跡と等しくなるよう，これら軌跡上の対応点間距離を目的関数とした設 計を行っている.

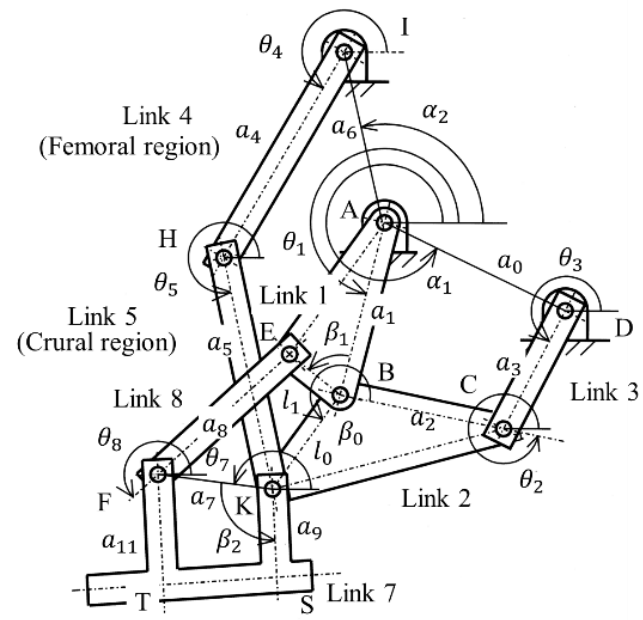

Fig. 3 The kinematic model of the motion transformer added with two links to guide the sole of a foot. All links in this motion transformer is connected by revolute pairs. Type I is called this.

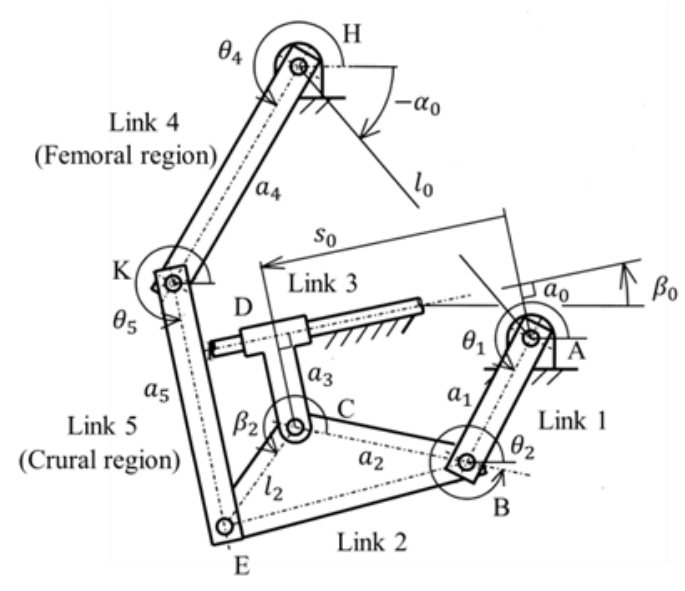

Fig. 5 The kinematic model of ankle free type obtained by modifying Type II. Two links is removed from the motion transformer shown in Fig. 4 in order to make the ankle joint free. Type II-ankle free is called this.

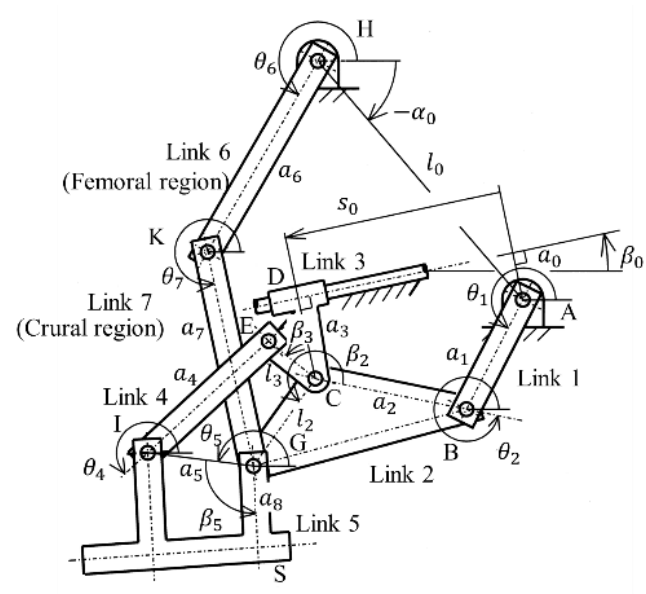

Fig. 4 The kinematic model using a sliding joint. The revolute pair is replaced by a sliding joint (prismatic pair) in Fig. 3. The longest link can be removed by using a sliding joint. Type II is called this.

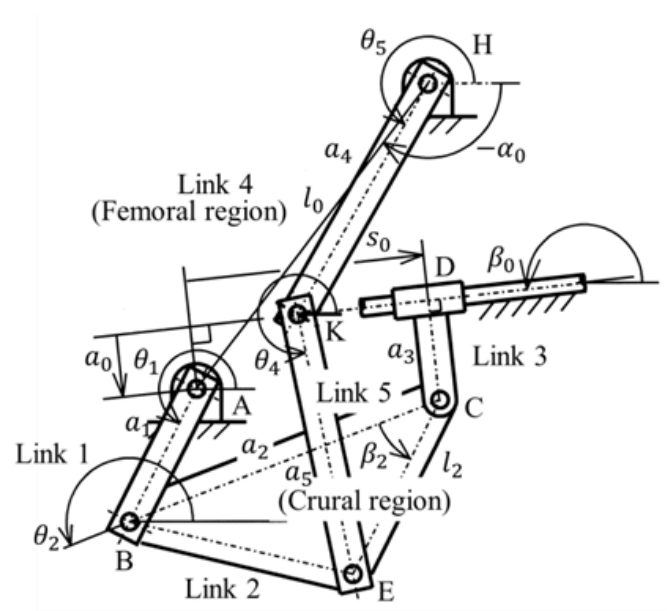

Fig. 6 The kinematic model of front wheel drive type. The crank shaft is put on the front of the walker. The approach from the rear to ride is easier than the other type of the walker. A slider-crank mechanism is used. An ankle motion of the uses is free. Type III is called this. 


\section{3. 歩行動作の測定}

設計に参照する軌跡を得るため脚部動作を測定する，図７に，脚部関節角変位測定装置を示す．この測定装置 は装着型であり，人体脚部の各関節にポテンショメータ(COPAL JT30-340-C00)の回転軸が一致するように取り付 ける.

その測定結果を用いて描いた足関節の軌跡を図 8 に示す。この図 8(a)は, I 形を設計する際に，図 8(b)は，II 形 および III 形を設計する際に参照した歩行の軌跡である. 本稿では被験者は，20 代男性としている．図中の直線 は大腿部および下腿部を表す平面リンク機構である. また, 股関節を固定点としており, リンク長はそれぞれ成 年男子の大腿部および下腿部の長さ $400[\mathrm{~mm}] お よ ひ ゙ 470[\mathrm{~mm}]$ (AIST 人体寸法データベース，2013)としている.

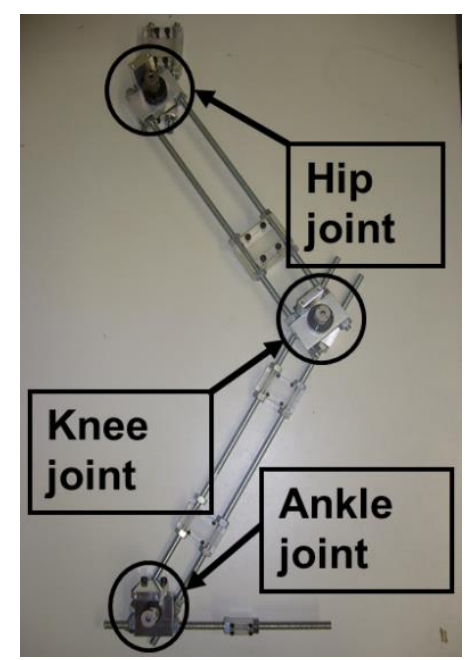

(a) The structure of the device. Axes of revolute pairs are put coaxially to human joints.

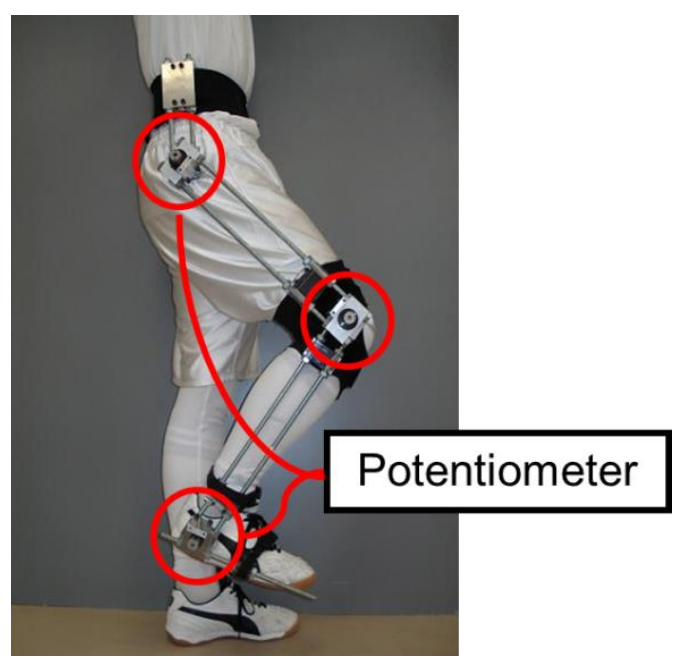

(b) The condition of the device put on human leg. Potentiometers are installed on revolute pairs of the wearable measurement device.

Fig. 7 The wearable device to measure the human leg motion .

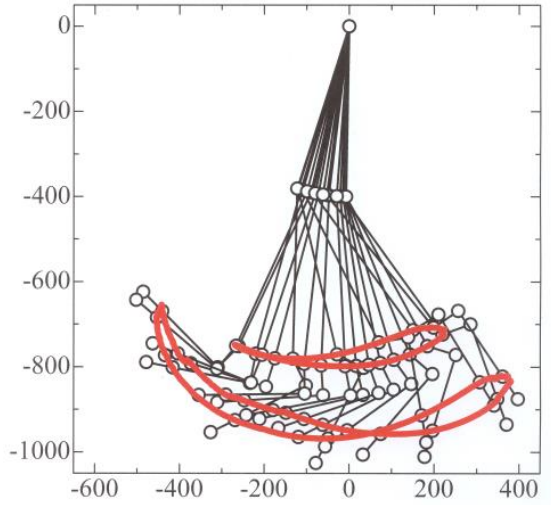

(a) The reference of human leg motion when designing Type I

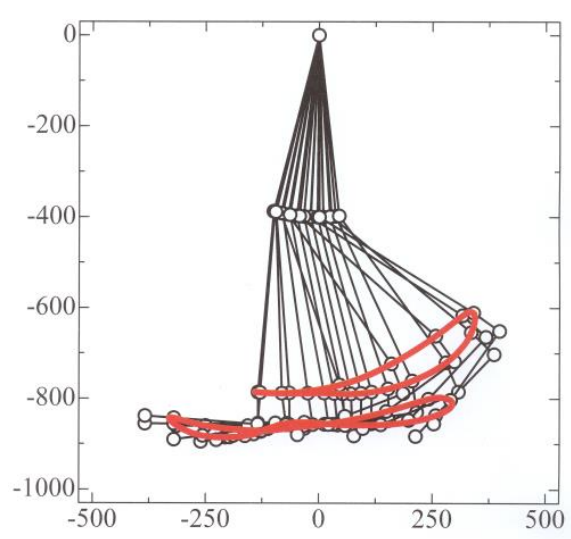

(b) The reference of human leg motion when designing Type II and III

Fig. 8 The walking motion of human leg to refer for designing the motion transformer. This motion is obtained by the method of using the measurement device shown in Fig. 7. 
図 9 および図 10 は，ぞれぞれ図 8(a)および図 8(b)の脚部動作を描くのに用いた関節角変位である. I 形の設計 においては被験者 1 名による歩行動作を参照していたのに対し， II 形および III 形の設計では被験者 5 名分，計 35 個のデータから平均した值を用いている.これは共通する歩行動作の特徵を抽出するために II 形以降の設計で 採用しているものである. いずれの図においても，サンプリング間隔は，2.5[ms] として，歩行動作 1 サイクル分 の測定結果を示している．また，約 36〜68\% において，遊脚相となっている.

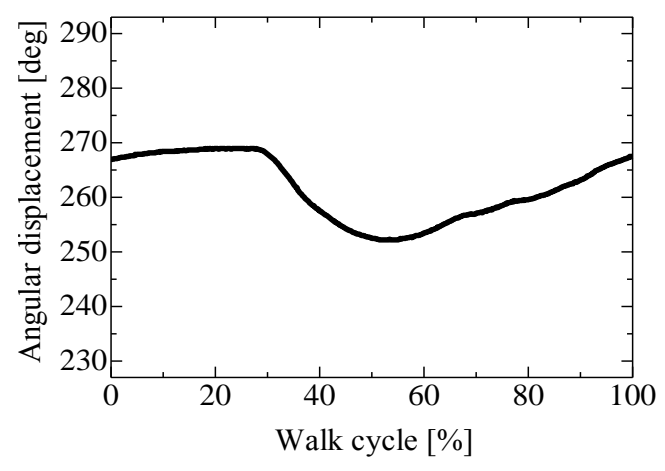

(a) The hip joint angular displacement

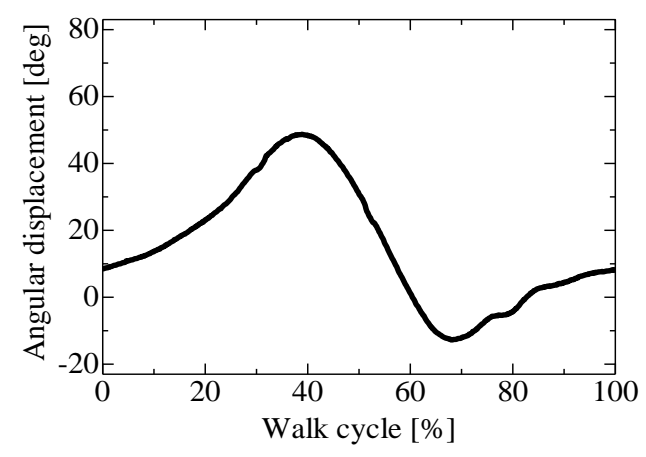

(b) The knee joint angular displacement

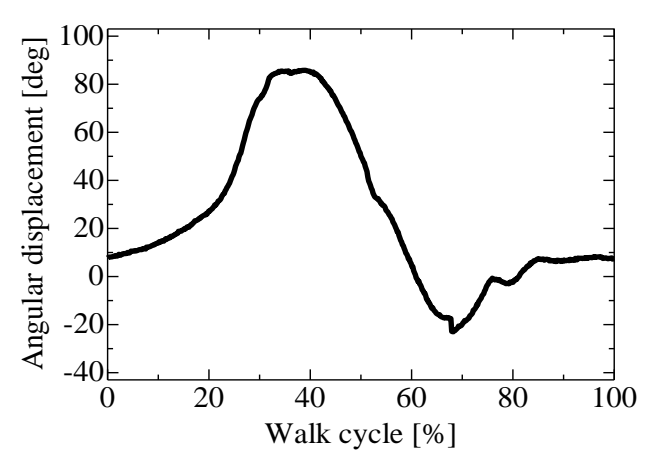

(c) The ankle joint angular displacement

Fig. 9 Angular displacements of human leg. These are used to draw the motion shown in Fig. 8 (a).

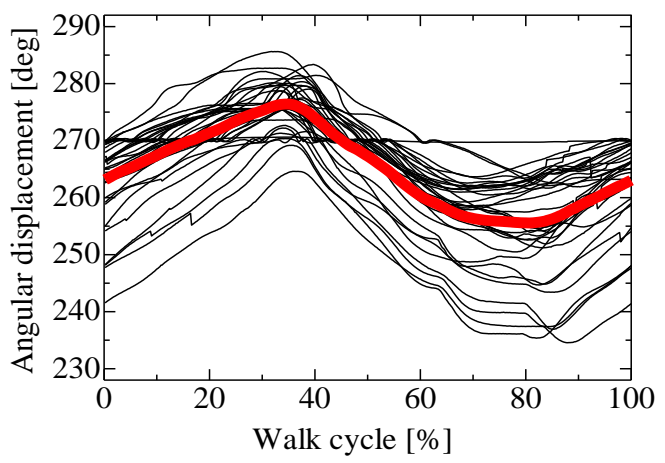

(a) The hip joint angular displacements

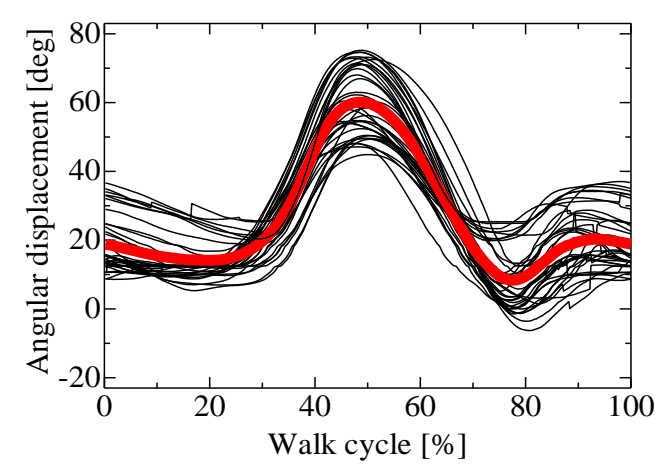

(b) The knee joint angular displacements

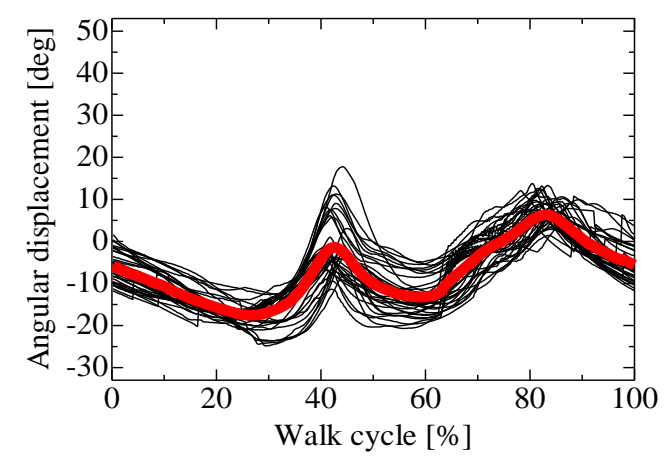

(c) The ankle joint angular displacements

Fig. 10 Angular displacements of human leg. These are used to draw the motion shown in Fig. 8 (b). In these figure, 35 data are shown. The red line shows the average value of these data. 


\section{4. 疑似歩行動作 - 回転運動変換機構の設計}

\section{$4 \cdot 1$ 運動学モデル}

本章では，I 形を例に運動変換機構の設計方法について述べる. I 形では，平面 4 節リンク機構の中間節点が歩 行時の足関節の軌跡を追従するよう機構定数を決定する。ささらに，足裏を案内する2つのリンクを追加し，平面 6 節リンク機構を用いて装置の設計を行う.

図 3 の運動学モデルを用いる. 図中，点 $\mathrm{A}, \mathrm{B}, \mathrm{C}, \mathrm{D}, \mathrm{E}$ および F は，対偶点であり，回転対偶を表す。また， 点 $\mathrm{I}, \mathrm{H}$ および $\mathrm{K}$ は股関節，膝関節および足関節を表す回転対偶である. 各対偶点での角変位は $\theta_{i} \quad(i=1 \sim 5$, $7,8)$ で表し，水平軸から反時計回りを正として表記している．また， $a_{i}(i=0 \sim 8)$ はリンク長（回転軸の中心距 離）を表す. Link 1 および Link 2 は 3 対偶素節であり，対偶点 $\mathrm{E}$ および $\mathrm{K}$ はそれぞれ角度 $\beta_{1}$ および $\beta_{0}$ ， 長さ $l_{1}$ および $l_{0}$ でその位置を表す.

\section{$4 \cdot 2$ 変位解析}

閉回路方程式を用いて変位解析式を誘導し, 車輪へ伝達する出力角を既知量として機構の姿勢 (対偶点の位置) を算出する.

以下に誘導された算出式を示す.

成分 4 節リンク機構ABCDにおいて，閉回路方程式を導き，出力軸に関する角変位 $\theta_{3}$ を既知量として， $\theta_{1}$ お よび $\theta_{2}$ が求められる.

$$
\begin{aligned}
& \overrightarrow{\mathrm{AB}}+\overrightarrow{\mathrm{BC}}+\overrightarrow{\mathrm{CD}}+\overrightarrow{\mathrm{DA}}=0 \\
& \overrightarrow{\mathrm{AB}}=a_{1} \cos \theta_{1} \boldsymbol{i}+a_{1} \sin \theta_{1} \boldsymbol{j} \\
& \overrightarrow{\mathrm{BC}}=a_{2} \cos \theta_{2} \boldsymbol{i}+a_{2} \sin \theta_{2} \boldsymbol{j} \\
& \overrightarrow{\mathrm{CD}}=-a_{3} \cos \theta_{3} \boldsymbol{i}-a_{3} \sin \theta_{3} \boldsymbol{j} \\
& \overrightarrow{\mathrm{DA}}=-a_{0} \cos \alpha_{1} \boldsymbol{i}-a_{0} \sin \alpha_{1} \boldsymbol{j}
\end{aligned}
$$

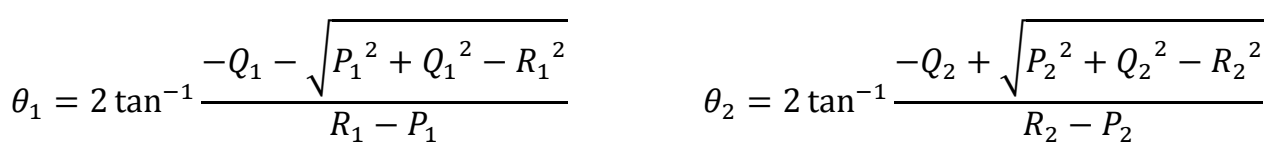

$$
\begin{aligned}
& \left.P_{1}=-2 a_{1}\left(a_{3} \cos \theta_{3}+a_{0} \cos \alpha_{1}\right)\right) \quad P_{2}=-2 a_{2}\left(a_{3} \cos \theta_{3}+a_{0} \cos \alpha_{1}\right) \\
& Q_{1}=-2 a_{1}\left(a_{3} \sin \theta_{3}+a_{0} \sin \alpha_{1}\right) \quad Q_{2}=-2 a_{2}\left(a_{3} \sin \theta_{3}+a_{0} \sin \alpha_{1}\right) \\
& R_{1}=2 a_{0} a_{3} \cos \left(\theta_{3}-\alpha_{1}\right)+a_{1}^{2} \quad R_{2}=2 a_{0} a_{3} \cos \left(\theta_{3}-\alpha_{1}\right)-a_{1}^{2} \\
& -a_{2}^{2}+a_{3}^{2}+a_{0}^{2} \\
& +a_{2}^{2}+a_{3}^{2}+a_{0}^{2}
\end{aligned}
$$

$\theta_{1}$ および $\theta_{2}$ の算出後，これらの值を既知量として，閉回路方程式 IHKBA により，股関節および膝関節に関 する角変位 $\theta_{4}$ および $\theta_{5}$ の值を算出する.

$\overrightarrow{\mathrm{IA}}+\overrightarrow{\mathrm{AB}}+\overrightarrow{\mathrm{BK}}+\overrightarrow{\mathrm{KH}}+\overrightarrow{\mathrm{HI}}=0$

$$
\left.\begin{array}{rl}
\overrightarrow{\mathrm{IA}} & =-a_{6} \cos \alpha_{2} \boldsymbol{i}-a_{6} \sin \alpha_{2} \boldsymbol{j} \\
\overrightarrow{\mathrm{BK}} & =l_{0} \cos \left(\theta_{2}+\beta_{0}\right) \boldsymbol{i}+l_{0} \sin \left(\theta_{2}+\beta_{0}\right) \boldsymbol{j} \\
\overrightarrow{\mathrm{KH}} & =-a_{5} \cos \theta_{5} \boldsymbol{i}-a_{5} \sin \theta_{5} \boldsymbol{j} \\
\overrightarrow{\mathrm{HI}} & =-a_{4} \cos \theta_{4} \boldsymbol{i}-a_{4} \sin \theta_{4} \boldsymbol{j}
\end{array}\right\}
$$




$$
\theta_{4}=2 \tan ^{-1} \frac{-Q_{4}+\sqrt{P_{4}{ }^{2}+Q_{4}{ }^{2}-R_{4}^{2}}}{R_{4}-P_{4}} \quad \theta_{5}=2 \tan ^{-1} \frac{-Q_{5}+\sqrt{P_{5}{ }^{2}+Q_{5}{ }^{2}-R_{5}{ }^{2}}}{R_{5}-P_{5}}
$$

$$
\begin{aligned}
& P_{4}=-2 a_{4}\left\{a_{1} \cos \theta_{1}+l_{0} \cos \left(\theta_{2}+\beta_{0}\right)-a_{6} \cos \alpha_{2}\right\} \\
& Q_{4}=-2 a_{4}\left\{a_{1} \sin \theta_{1}+l_{0} \sin \left(\theta_{2}+\beta_{0}\right)-a_{6} \sin \alpha_{2}\right\} \\
& R_{4}=2 a_{1} l_{0} \cos \left(\theta_{1}-\theta_{2}-\beta_{0}\right)-2 a_{6} l_{0} \cos \left(\theta_{2}-\alpha_{2}+\beta_{0}\right) \\
& \left.-2 a_{1} a_{6} \cos \left(\theta_{1}-\alpha_{2}\right)+a_{1}{ }^{2}+a_{4}{ }^{2}-a_{5}{ }^{2}+a_{6}{ }^{2}+l_{0}{ }^{2}\right) \\
& P_{5}=-2 a_{5}\left\{a_{1} \cos \theta_{1}+l_{0} \cos \left(\theta_{2}+\beta_{0}\right)-a_{6} \cos \alpha_{2}\right\} \\
& Q_{5}=-2 a_{5}\left\{a_{1} \sin \theta_{1}+l_{0} \sin \left(\theta_{2}+\beta_{0}\right)-a_{6} \sin \alpha_{2}\right\} \\
& R_{5}=2 a_{1} l_{0} \cos \left(\theta_{1}-\theta_{2}-\beta_{0}\right)-2 a_{6} l_{0} \cos \left(\theta_{2}-\alpha_{2}+\beta_{0}\right) \\
& \left.-2 a_{1} a_{6} \cos \left(\theta_{1}-\alpha_{2}\right)+a_{1}{ }^{2}-a_{4}{ }^{2}+a_{5}{ }^{2}+a_{6}{ }^{2}+l_{0}{ }^{2}\right\}
\end{aligned}
$$

さらに, 出力角変位 $\theta_{3}$ および角変位 $\theta_{1}, \theta_{2}$ および $\theta_{4}, \theta_{5}$ の值を既知量として, $\theta_{7}$ および $\theta_{8}$ の算出式を 誘導する.

$$
\left.\begin{array}{l}
\overrightarrow{\mathrm{BK}}+\overrightarrow{\mathrm{KF}}+\overrightarrow{\mathrm{FE}}+\overrightarrow{\mathrm{EB}}=0 \\
\overrightarrow{\mathrm{KF}}=a_{7} \cos \theta_{7} \boldsymbol{i}+a_{7} \sin \theta_{7} \boldsymbol{j} \\
\overrightarrow{\mathrm{FE}}=-a_{8} \cos \theta_{8} \boldsymbol{i}-a_{8} \sin \theta_{8} \boldsymbol{j} \\
\overrightarrow{\mathrm{EB}}=l_{1} \cos \left(\theta_{1}+\beta_{1}\right) \boldsymbol{i}+l_{1} \sin \left(\theta_{1}+\beta_{1}\right) \boldsymbol{j}
\end{array}\right\}
$$

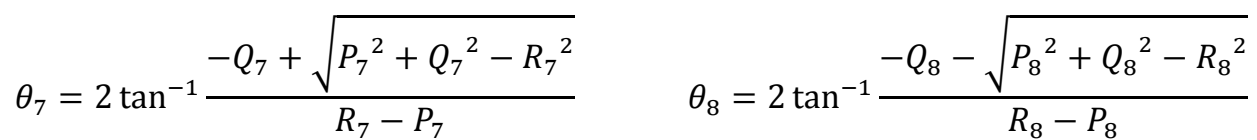

$$
\left.\left.\begin{array}{l}
P_{7}=2 a_{7}\left\{l_{0} \cos \left(\theta_{2}+\beta_{0}\right)+l_{1} \cos \left(\theta_{1}+\beta_{1}\right)\right\} \\
\left.\begin{array}{c}
Q_{7}=2 a_{7}\left\{l_{0} \sin \left(\theta_{2}+\beta_{0}\right)+l_{1} \sin \left(\theta_{1}+\beta_{1}\right)\right\} \\
R_{7}=2 l_{0} l_{1} \cos \left(\theta_{2}-\theta_{1}+\beta_{0}-\beta_{1}\right)+a_{7}{ }^{2}-a_{8}{ }^{2} \\
\quad+l_{0}{ }^{2}+l_{1}{ }^{2}
\end{array}\right\}
\end{array}\right\} \begin{array}{l}
P_{8}=-2 a_{8}\left\{l_{0} \cos \left(\theta_{2}+\beta_{0}\right)+l_{1} \cos \left(\theta_{1}+\beta_{1}\right)\right\} \\
Q_{8}=-2 a_{8}\left\{l_{0} \sin \left(\theta_{2}+\beta_{0}\right)+l_{1} \sin \left(\theta_{1}+\beta_{1}\right)\right\} \\
R_{8}=2 l_{0} l_{1} \cos \left(\theta_{2}-\theta_{1}+\beta_{0}-\beta_{1}\right)-a_{7}{ }^{2}+a_{8}{ }^{2} \\
\multicolumn{1}{c}{+l_{0}{ }^{2}+l_{1}{ }^{2}}
\end{array}\right\}
$$

2 次方程式の解において，2つある解のうちどちらを採用するかは数值解析の結果により決定している.

\section{$4 \cdot 3$ 機構定数の探索}

平面 4 節リンク機構の設計すなわち機構定数の決定には，歩行時の足関節中心と装置を構成する平面リンク機 構上の点 $\mathrm{K}$ (図 3 参照) を対応点とし，これらの相対距離を評価関数として行う.

機構の総合には，曲線照合(渡辺他，1995，許他，2001）を用いている.この手法は，製作したカム板を所望の 入出力関係が得られるよう，取付誤差の僅少化を図るためや，本論文のように平面 4 節リンク機構の中間節が描 く曲線（創成曲線）を必要とする曲線（理想曲線）に一致させるために用いられる．後者の機構では，機構の描 く軌跡のみを取扱いの対象とした運動創成機構（あるいは剛体案内機構）の設計手法として用いているが，本論 文では，出力軸の等速 1 回転で歩行 1 サイクルの脚部動作を再現する関数創成機構の設計手法としても用いてい る. 寸なわち，歩行動作 1 サイクルを第 3 章に示したように，一定のサンプリング間隔で約 500〜600 個分のデー タとして測定し，その点の数と同数の点を得るため，出力軸を一定量ずつ回転させて創成曲線上の点として対応 
させている.これら対応点間距離を，歩行 1 サイクル（出力軸 1 回転）で総和をとったものを目的関数として機 構の総合を行うことで, 歩行の疑似動作とその動作による等速での出力軸の回転（訓練器の移動）を得ることを 目指す.

ここで， $x_{W i}$ および $y_{W i}$ は，第 3 章で示した方法により測定した結果を用いて，股関節の回転中心を原点と する座標系において, 歩行時に足関節中心の描く軌跡 (理想曲線) 上の点の $x$ および $y$ 座標である. 一方, $x_{\mathrm{K} i}$ お よび $y_{\mathrm{K} i}$ は，同様の座標系において，図 3 における Link 2 上の対偶点 $\mathrm{K}$ が，出力角変位 $\theta_{3}$ を一定間隔で増 加させた時に描く軌跡（創成曲線）上の点の $x$ および $y$ 座標である. このとき $i$ は, 歩行 1 サイクル分を一定 の時間間隔で分割したときのデータの番号を表している.

$$
\begin{aligned}
& Q_{1}=\left(x_{\mathrm{K} i}-x_{\mathrm{W} i}\right)^{2}+\left(y_{\mathrm{K} i}-y_{\mathrm{W} i}\right)^{2} \\
& L_{1}=\frac{1}{n} \sum_{i=1}^{n} Q_{1}{ }^{1 / 2}
\end{aligned}
$$

ただし, $L_{1}$ は対応点間距離の平均を表し, $n$ は歩行 1 サイクルの分割数を表す.ここで, I 形の設計では, $n=587$ としている，一方，II 形以降の設計では， $n=500$ である.

また， $i=1$ とした $x_{W 1}$ および $y_{W 1}$ は，対応開始点を表すが，それは，創成曲線の開始点である $x_{\mathrm{K} 1}$ および $y_{\mathrm{K} 1}$ を $\theta_{3}=0$ としたとき, 理想曲線を分割したすべての点で総当たりの比較を行い, 決定している.

また, 歩行動作中の足関節变位と装置使用時のペダル角度の差を小さくするため, 以下の目的関数も採用して いる.

$$
\begin{aligned}
& Q_{b}=\left\{\left(\theta_{\mathrm{IW} i}+\theta_{\mathrm{HW} i}+\theta_{\mathrm{KW} i}\right)-\left(\theta_{7 i}+\beta_{2}\right)\right\}^{2} \\
& L_{Q b}=\frac{1}{n} \sum_{i=1}^{n} Q_{b}{ }^{1 / 2}
\end{aligned}
$$

式(10)および式(12)に示した目的関数を使用する一方，以下に示寸制約条件も採用する.

1. 乱数で与えられたリンク長で点 $\mathrm{ABCD}$ を通過して閉回路を構成し, Link 3 が 1 回転できること

$$
a_{3}+a_{0} \leq a_{1}+a_{2}, \quad a_{3}+a_{1} \leq a_{0}+a_{2}, \quad a_{3}+a_{2} \leq a_{0}+a_{1},
$$

2. 対応点間距離と理想曲線との比が $3 \%$ 以内であること

$$
L_{1} / L_{W} \leq 3 \% \quad \text { ただし， } L_{W} \text { は理想曲線の長さを表す. }
$$

3. 創成曲線と理想曲線の長さの比が $0.8 \sim 1.2 \%$ の範囲にあること

$$
0.8 \% \leq L_{K} / L_{W} \leq 1.2 \% \quad \text { ただし， } L_{K} \text { は創成曲線の長さを表す. }
$$

4. 歩行時の足関節角変位と歩行器のペダルの角変位の差の, 歩行時の足関節の運動領域との比が $10 \%$ 以内で あること（図 11 および図 12 参照)

$$
L_{Q b} / L_{\theta A} \leq 10 \%
$$

ただし, $L_{\theta A}=\left(\theta_{\mathrm{IW} i}+\theta_{\mathrm{HW} i}+\theta_{\mathrm{KW} i}\right)_{\max }-\left(\theta_{\mathrm{IW} i}+\theta_{\mathrm{HW} i}+\theta_{\mathrm{KW} i}\right)_{\min }$ である.

以上の手法をフローチャートとして図 13 にまとめる. 図中, 制約条件 1 4 は, 上記の $1 \sim 4$ に対応し, 探索の 第 1 段階として, 図 2 に示す平面 4 節リンク機構に対応する機構定数 $a_{0} \sim a_{6}, l_{0}, \alpha_{1}, \alpha_{2}$ および $\beta_{0}$ を決定し, 第 2 段階として, 足部を置く Link 7 を案内する機構定数 $a_{7}, a_{8}, a_{10}, a_{11}, l_{1}, \beta_{1}$ および $\beta_{2}$ を決定する.

II（足部拘束なし）形では, 足裏の案内を行わないので, 第 2 段階での探索は不要であり, 基本的に第 1 段階 での探索と同じである.

乱数の発生回数は $10^{6}$ とし, 探索の範囲は, ギャレットの公式 (Garrett, et al., 1968) を参考とし, 以下のように与 えている. 


$$
a_{0}, a_{1}, a_{2}, a_{3}, a_{7}, a_{8}=\left\{\begin{array}{l}
120 U_{j}+40\left(0 \leq U_{j} \leq 0.5\right) \\
600 U_{j}-200\left(0.5 \leq U_{j} \leq 1\right)
\end{array} \quad(j=0 \sim 5)\right.
$$

ここで, $U_{j}$ は, 区間 $[0,1]$ 内の值をとる一様乱数を表している. また, 3 対偶素節の対偶点を与える定数 $l_{0}, \beta_{0}, l_{1}$ お よび $\beta_{1}$ は，対偶点 $\mathrm{E}$ および対偶点 $\mathrm{K}$ が，それぞれ線分 $\mathrm{AB}$ および線分 $\mathrm{BC}$ の中点を中心とし，半径を

$$
a=\frac{a_{0}+a_{1}+a_{2}+a_{3}}{4}
$$

\section{とする円内に配置できるように決定している.}

乱数を用いて機構定数を与え, 制約条件を満たした機構定数の中から, 人体との干渉がなく, 目的関数の值が 最も小さくなるもの選択し, I 形の機構定数として以下に示す.

$$
\begin{aligned}
a_{0} & =371.60, a_{1}=427.37, a_{2}=199.81, a_{3}=120.12, a_{6}=280.65, a_{7}=203.53, \\
a_{8} & =297.55, l_{0}=162.55, l_{1}=71.28[\mathrm{~mm}], \\
\alpha_{1} & =298.21, \alpha_{2}=83.02, \beta_{0}=260.79, \beta_{1}=1.83, \beta_{2}=100.98[\mathrm{deg}] \\
a_{4} & =400, a_{5}=470, a_{9}=80[\mathrm{~mm}] \\
L_{1} & =31.14[\mathrm{~mm}] L_{Q b}=10.19[\mathrm{deg}]
\end{aligned}
$$

同様の手法から得られた II 形の機構定数は以下のとおりである．ただし，II 形以降の設計では，探索の範囲は あらかじめ限定はせず，I 形の機構定数を参考に探索し，人体との干渉および目的関数の值を考慮し以下の值と している.

$$
\begin{aligned}
a_{0} & =48.62, a_{1}=128.32, a_{2}=324.58, a_{3}=244.72, a_{4}=288.16, a_{5}=164.46, l_{0}=519.53, l_{2}=198.35, \\
l_{3} & =99.77[\mathrm{~mm}], \alpha_{0}=-65.06, \beta_{0}=1.65, \beta_{2}=272.35, \quad \beta_{3}=20.56, \quad \beta_{5}=229.87[\mathrm{deg}]
\end{aligned}
$$

また，III 形の機構定数は以下のとおりである. このとき，リンクの人体との干渉，クランクの床との干渉およ び目的関数の值を考慮し, 以下の值としている.

$$
\begin{aligned}
& a_{0}=-18.49, a_{1}=207.34, a_{2}=339.36, a_{3}=150.49, l_{0}=768.00, l_{2}=46.81[\mathrm{~mm}], \alpha_{0}=260.83, \\
& \beta_{0}=198.69, \beta_{2}=35.41[\mathrm{deg}]
\end{aligned}
$$

この機構定数を用いて, $4 \cdot 2$ 項の手法により得られる装置使用時の脚部動作のシミュレーション結果を図 14 に示す．図中，太線は足部が最も前方にあるとき，および最も後方にあるときの脚部姿勢を示している．これら の図において赤線は足関節および拇指関節の描く軌跡を示している. ただし, 図 14(c)は, 機構に足裏の案内のな いIII 形であるので，シミュレーションで拇指関節の軌跡を得ることはできないため，その軌跡は示していない．

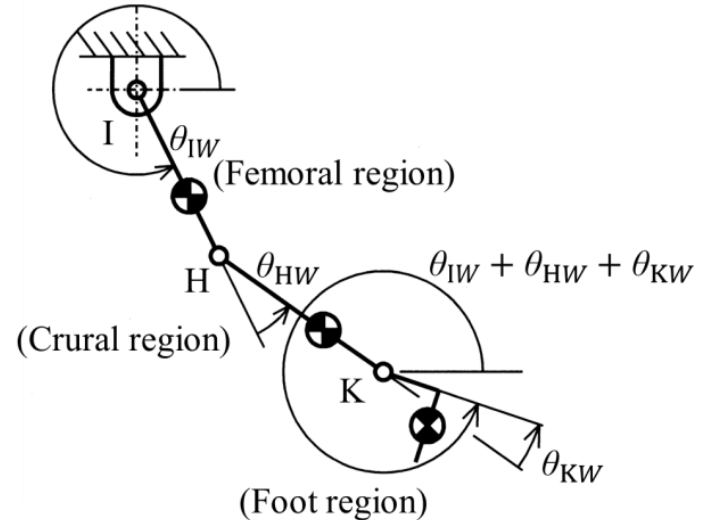

Fig. 11 Angular displacements of the human leg. Angular displacements are determining using the kinematic model as shown.

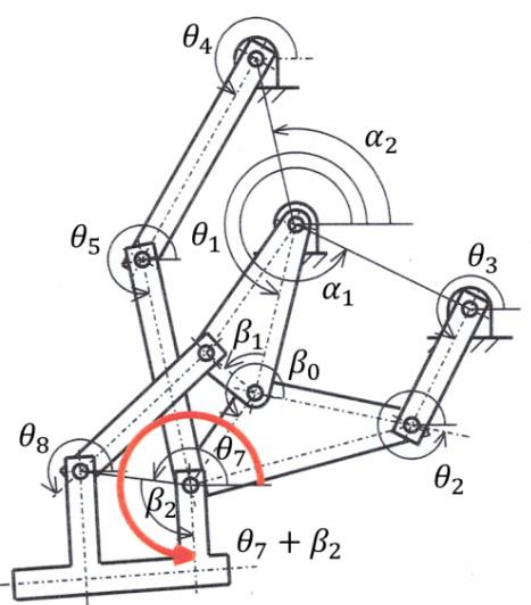

Fig. 12 The angular displacement of the ankle joint of Type I. The angular displacement is determined in the kinematic model (Type I). 
また, 対応点間距離の平均值は, 式(11)を用いて以下のように算出される.

Type I : $31.14[\mathrm{~mm}] \quad$ Type II : $48.84[\mathrm{~mm}] \quad$ Type III : $43.85[\mathrm{~mm}]$
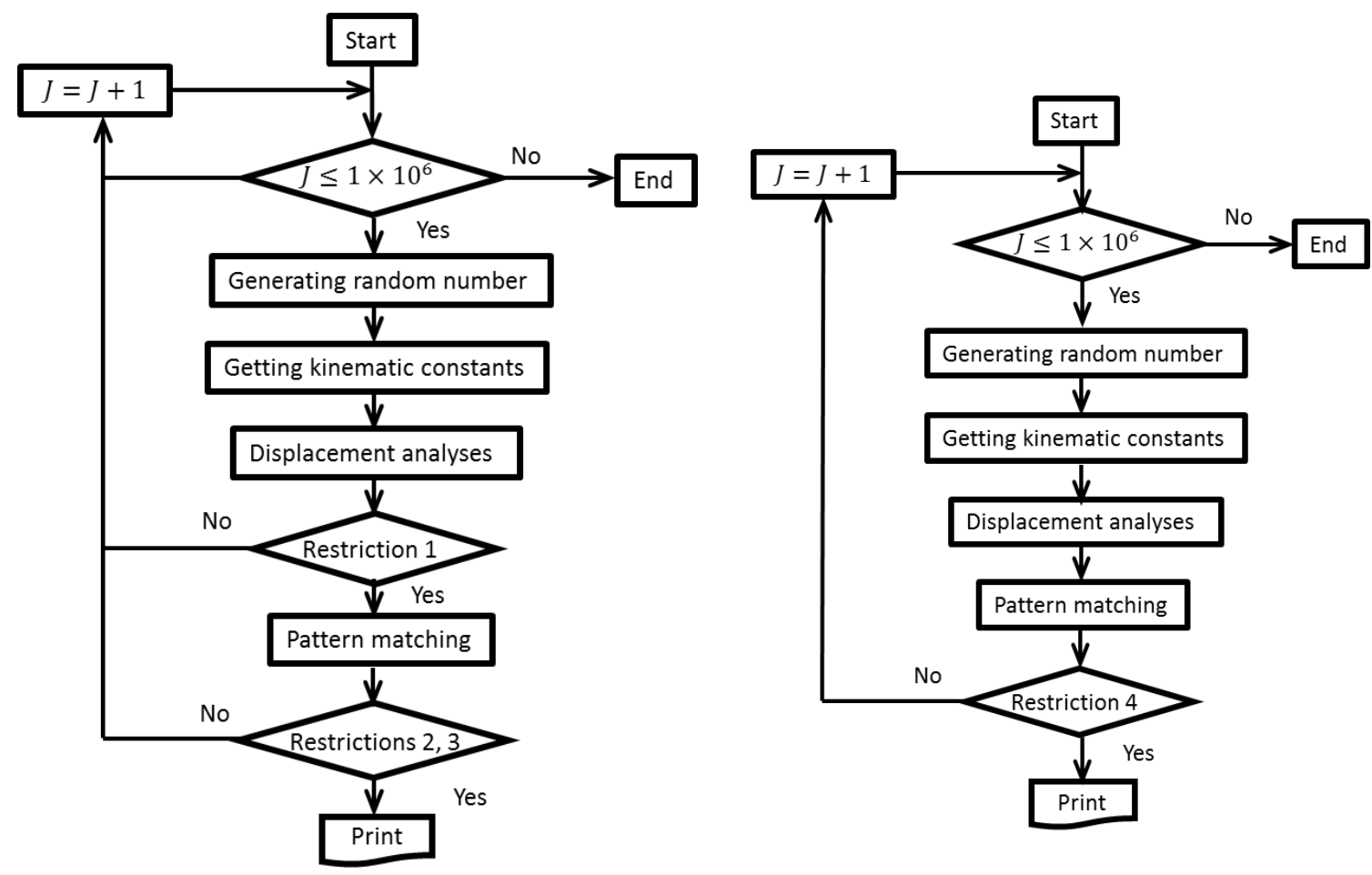

(a) The first stage of the flowchart. In the first stage,

(b) The second stage of the flowchart. In the second stage, kinematic constants for tracing the trajectory of the ankle joint are obtained. kinematic constants for guiding the sole of a foot are obtained.

Fig. 13 The flowchart for searching kinematic constants. The method is divided into two stages.

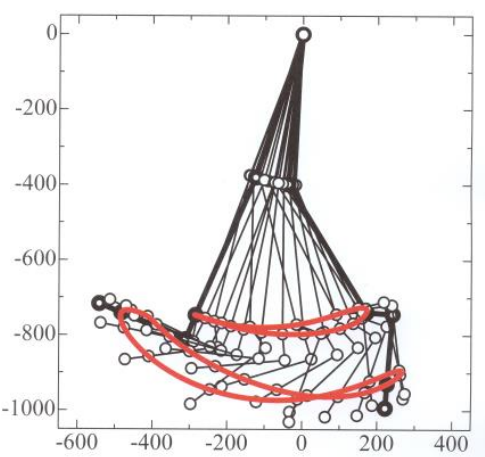

(a) The human leg motion using the kinematic constants searched by the method shown in the section 4 for Type I.

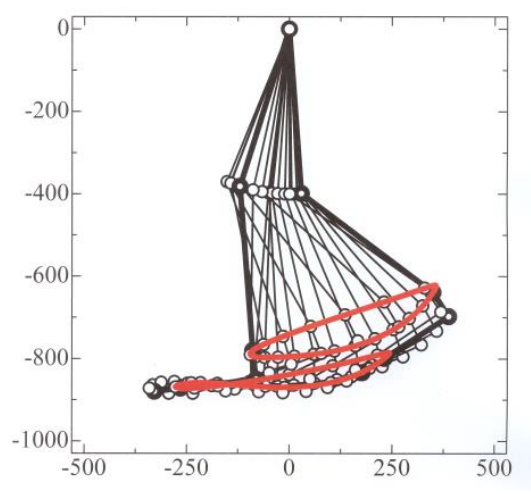

(b) The human leg motion using the kinematic constants searched by the similar method shown in the section 4 for Type II.

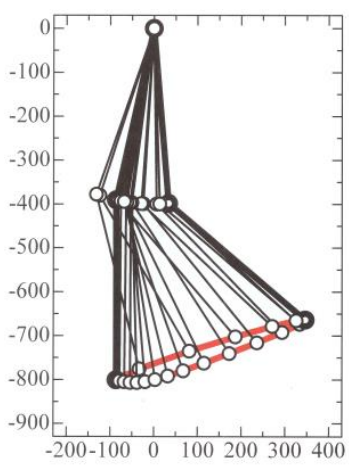

(c) The human leg motion using the kinematic constants searched by the similar method shown in the section 4 for Type III.

Fig. 14 The Simulation of the human leg motion. These motions are obtained by the method of simulating to compare the reference motion. In these figure, thick lines indicates the attitude of leg when the foot is the forefront and aftermost position. Red lines indicate the trajectories of ankle joint and metacarpophalangeal joint (MP joint). Because the user's ankle joint is free in Type III, the trajectory of MP joint is not shown in figure (c). 


\section{5. 試作および実験}

\section{$5 \cdot 1$ 試作}

前章に示した数值を用いて試作した装置を図 15 に示す.疑似歩行動作 - 回転運動変換機構の出力軸から車軸へ の運動伝達には，ベルト・プーリ機構を用いている.

\section{$5 \cdot 2$ 装置使用時の脚部動作の測定}

試作した装置について評価のための実験を行った。装置使用時の脚部動作の測定には図 7 に示す装置を用いて いる. この測定結果から得られる脚部の運動状況を図 16 に示す.このときの脚部角変位を図 17 亿に示す。ま た，被験者はいずれも 20 代男性であり，同一の被験者 1 名（身長 $170[\mathrm{~cm}]$, 体重 62[kg]）で行っている.

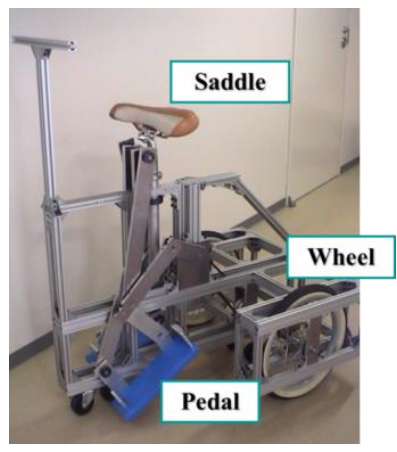

(a) Walker with the motion transformer (Type I) using the planar 6-link mechanism

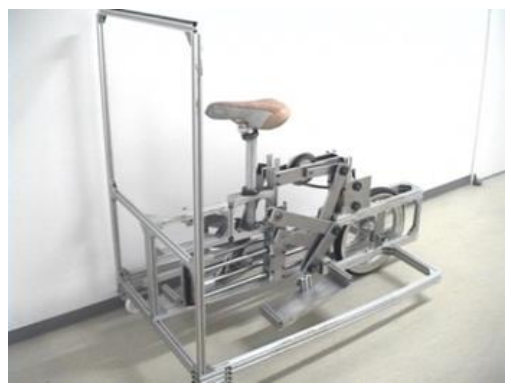

(b) Walker with the motion transformer (Type II) using the planar 6-link mechanism including the slider joint

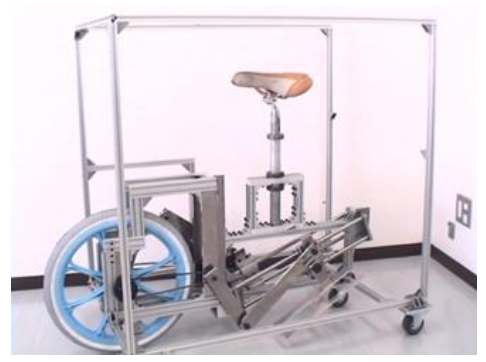

(c) Walker with the motion transformer (Type III) using the slider-crank mechanism. In this type, the driving shaft is installed on the front of the walker in order to make the approach from the rear to ride easier, and the ankle motion is free

Fig. 15 Experimental devices of the walker with simulated waking-rotational motion transformer. These devices are manufactured using kinematic constants searched by the method shown in the section 4 .

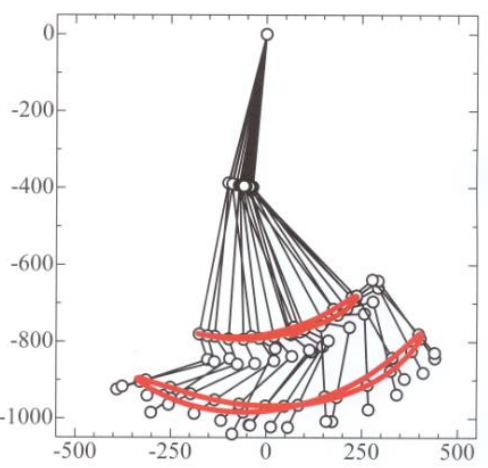

(a) The result of measurement using the walker (Type I).

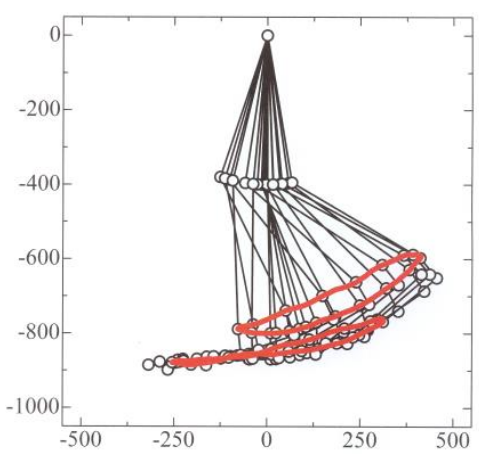

(b) The result of measurement using the walker (Type II)

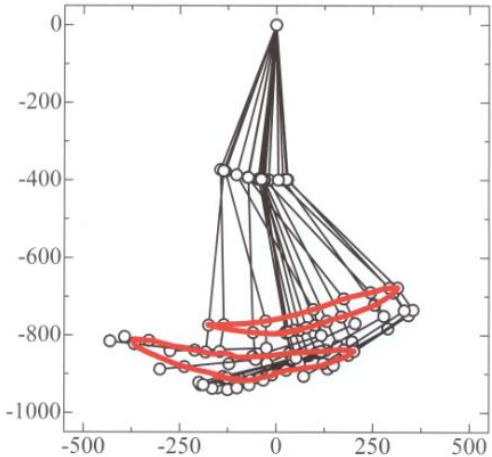

(c) The result of measurement using the walker (Type III)

Fig. 16 Human leg motions of the measurement using the motion transformer. These motions are measured by the device shown in Fig. 7. 


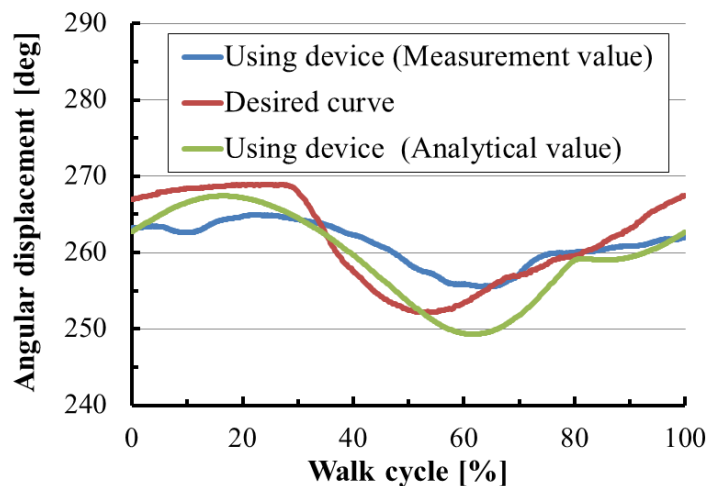

(a) The angular displacements of a hip joint

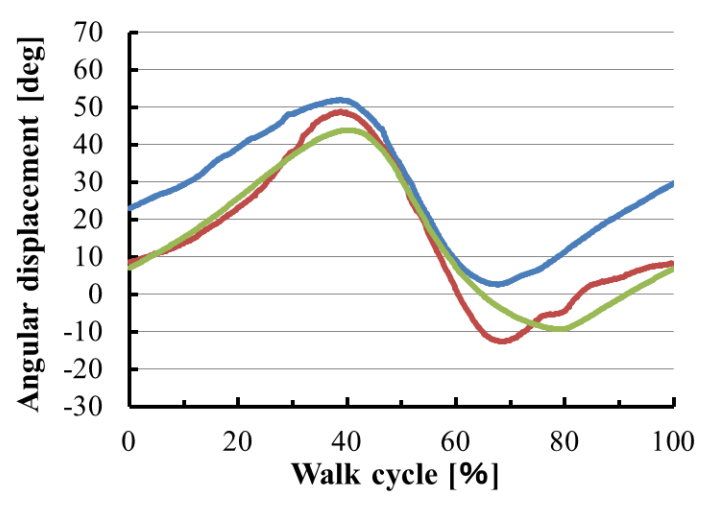

(b) The angular displacements of a knee joint

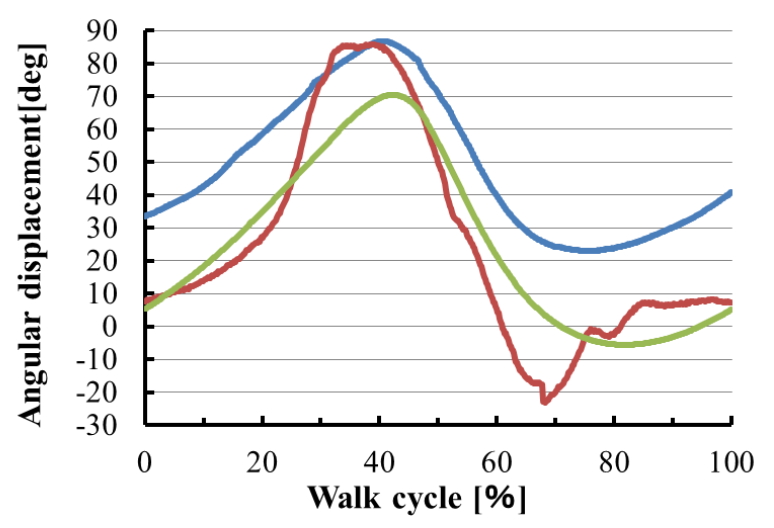

(c) The angular displacements of an ankle joint

Fig. 17 Measurement values of angular displacements of the human leg using the motion transformer (Type I) compared with the reference and the simulated motions. The blue line indicates the measurement value of using the motion transformer. The green line indicates the analytical value of using the motion transformer. The red line indicates the desired curve obtained from the reference motion shown in Fig. 8(a).

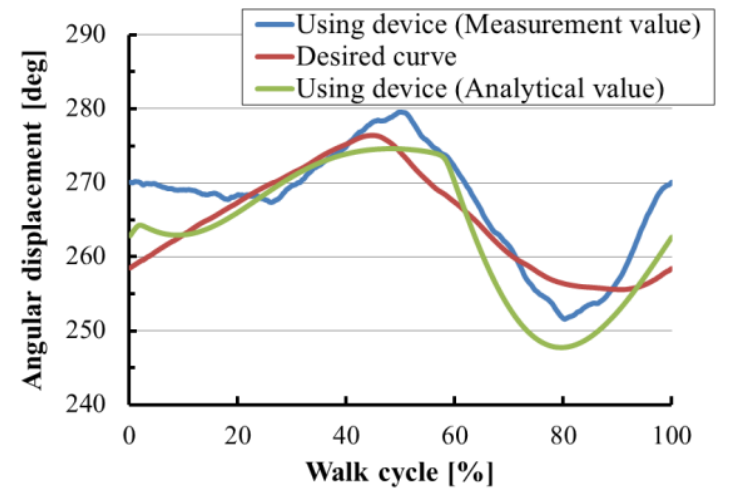

(a) The angular displacements of a hip joint

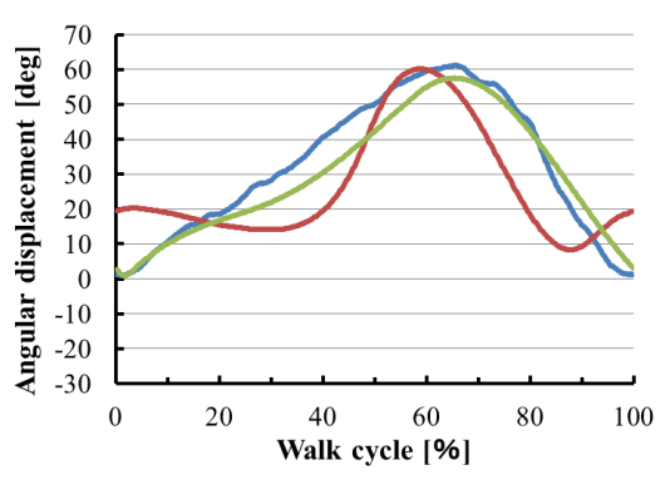

(b) The angular displacements of a knee joint

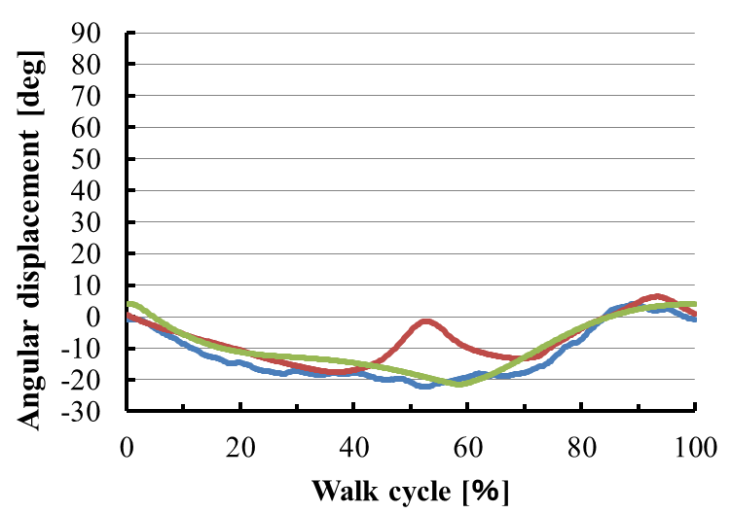

(c) The angular displacements of an ankle joint

Fig. 18 Measurement values of angular displacements of the human leg using the motion transformer (Type II) compared with the reference and the simulated motions. The blue line indicates the measurement value of using the motion transformer. The green line indicates the analytical value of using the motion transformer. The red line indicates the desired curve obtained from the reference motion shown in Fig. 8(b). 


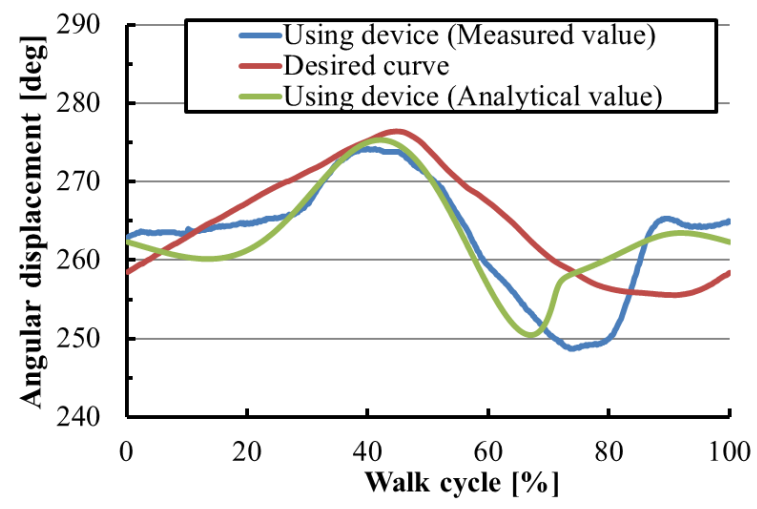

(a) The angular displacements of a hip joint

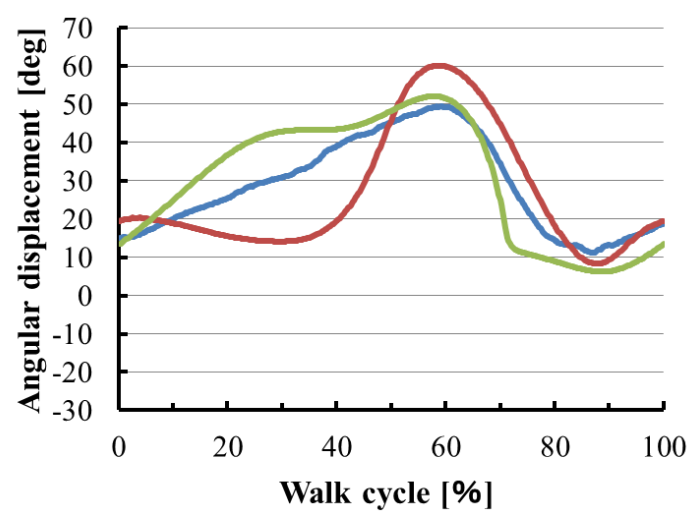

(b) The angular displacements of a knee joint

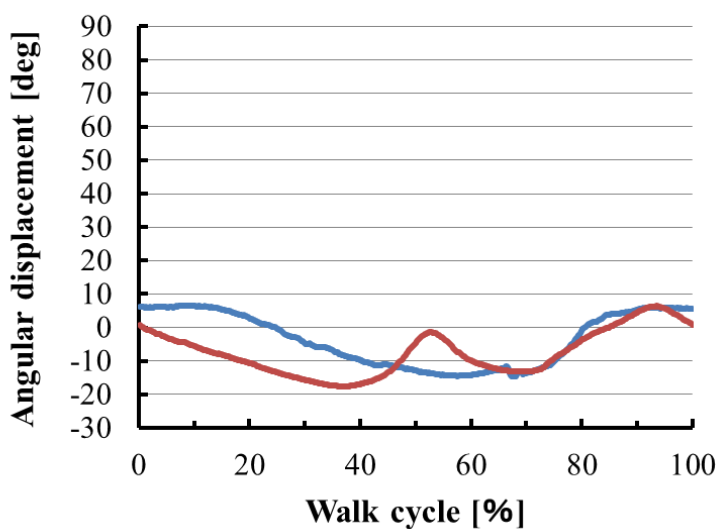

(c) The angular displacements of an ankle joint. In this case, when the design, the ankle joint motion is not using as the reference. Because the user's ankle is free in type III, the analytical value is not obtained.

Fig. 19 Measurement values of angular displacements of the human leg using the motion transformer (Type III) compared with the reference and the simulated motions. The blue line indicates the measurement value of using the motion transformer. The green line indicates the analytical value of using the motion transformer. The red line indicates the desired curve obtained from the reference motion shown in Fig. 8(b).

\section{$5 \cdot 3$ ペダル踏力の測定}

身体への負担を評価する目的でペダル踏力を図 20 に示寸装置で測定している. 測定した結果を図 21 に示す.また，図 22 には，図 21 に示した踏力のデータを 1 周期で整理した結果を示す. 図 中, 実線で区切られた領域は遊脚期であることを示している. 


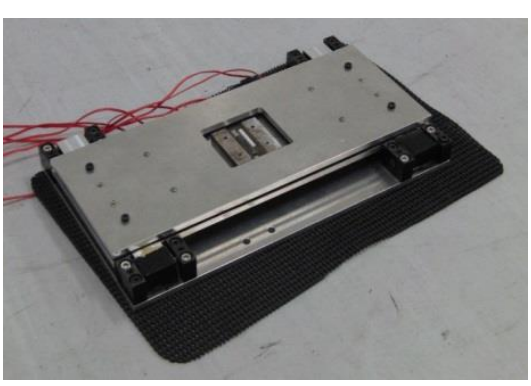

(a) The general view of the device

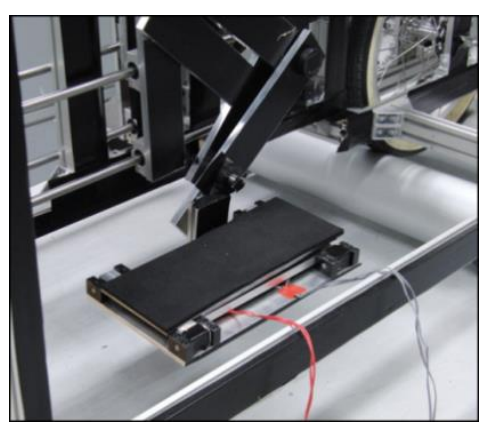

(b) The view of the device installed on the pedal of the walkers

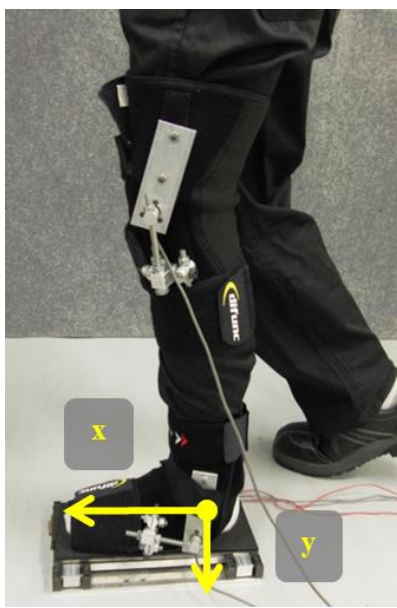

(c) The directions of the pedaling force measured by the device

Fig. 20 The device to measure the pedaling force. This device is manufactured using the strain gages.

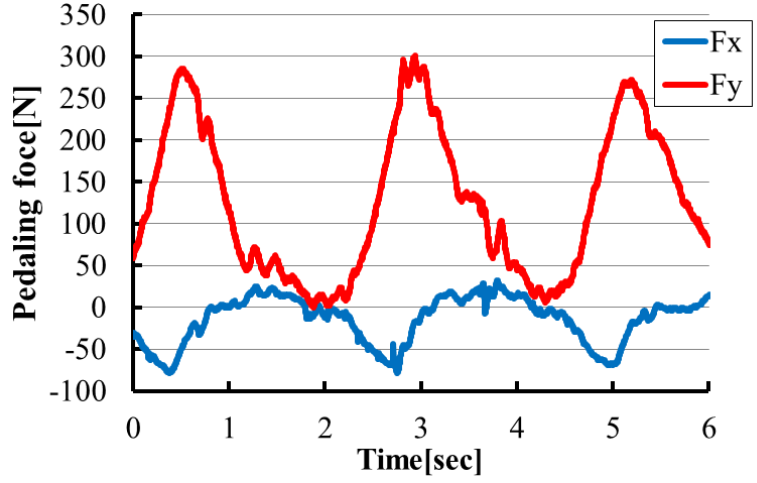

(a) The pedaling force of Type I

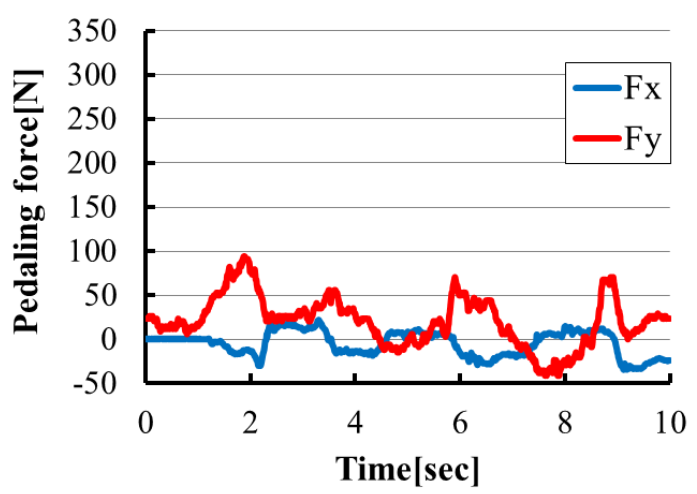

(c) The pedaling force of Type II-ankle free. Comparing with the result of measuring Type II, The maximum value is $1 / 3$, shown in this figure.

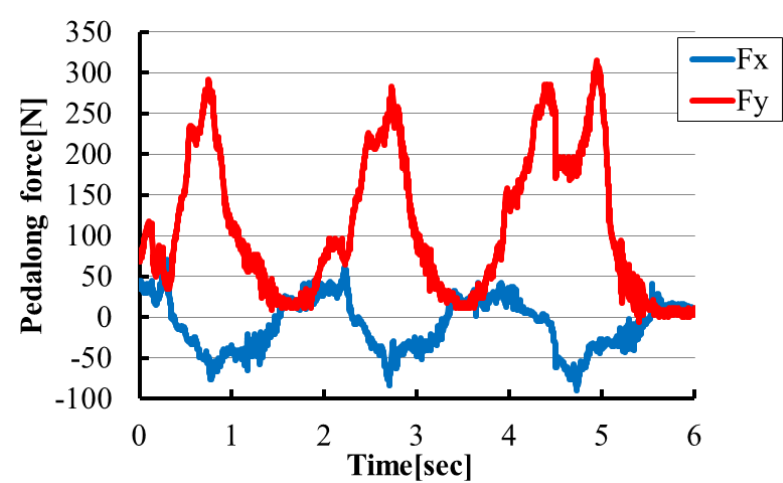

(b) The pedaling force of Type II

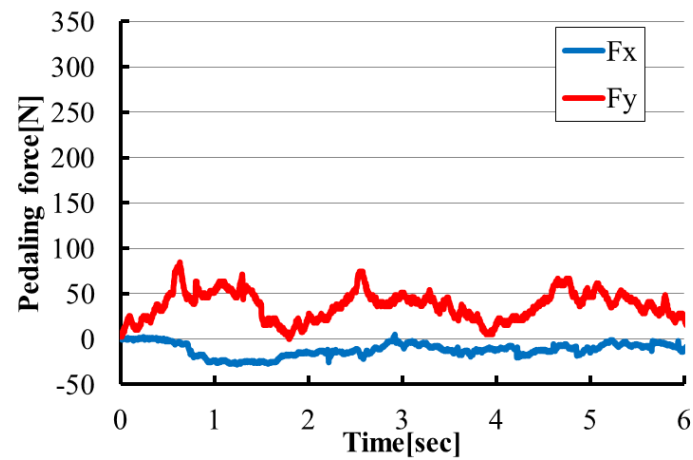

(d) The pedaling force of Type III. Making the ankle joint free when the using the motion transformer, the maximum values are smaller.

Fig. 21 The results of the pedaling forces. These values are measured by the device shown in Fig. 20. The blue line indicates the $\mathrm{x}$-direction of the pedaling force Fx. The red line indicates the y-direction of the pedaling force Fy. 
また，図 23〜図 25 には，脚部姿勢に足裏からペダルに作用する踏力の向きを表示している. 図 26 には, 歩行 時での床への踏力を示している. ただし，ベクトルの大きさは踏力の大きさを反映していない.

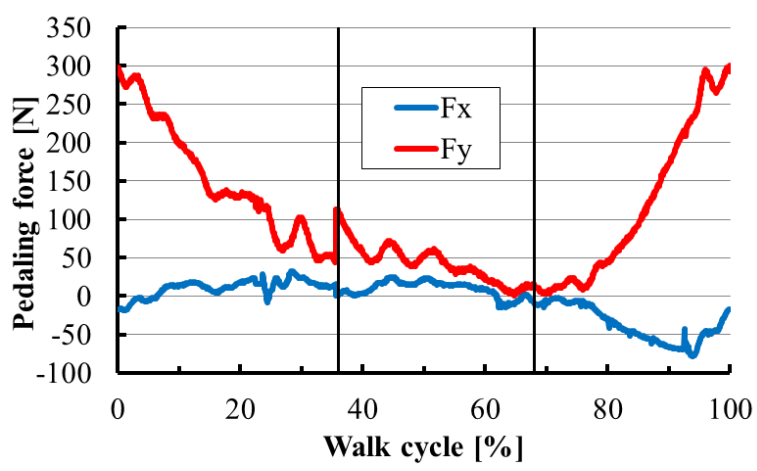

(a) The pedaling force of Type I

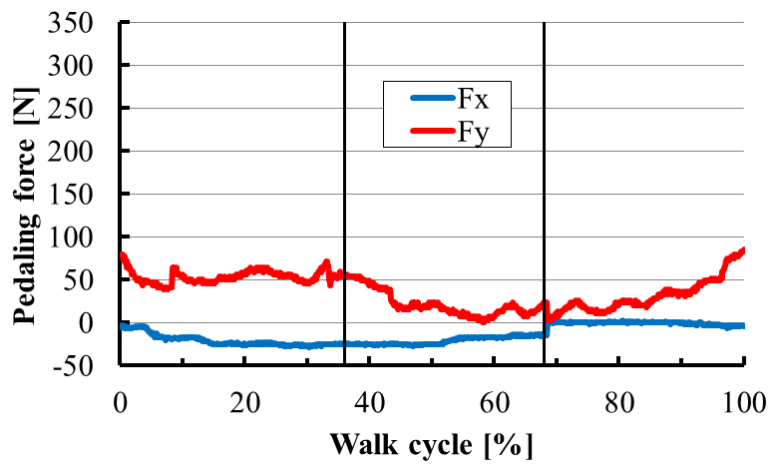

(c) The pedaling force of Type III

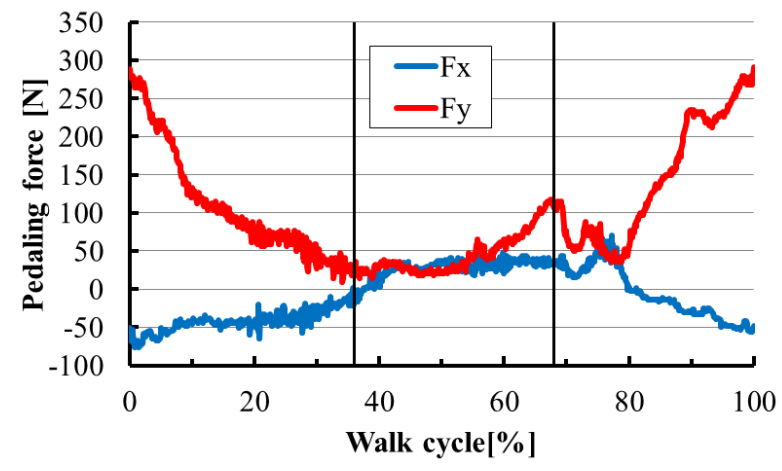

(b) The pedaling force of Type II

Fig. 22 The pedaling force in ordinate and the walk cycle in abscissa. The range dividing two lines is swing phase.

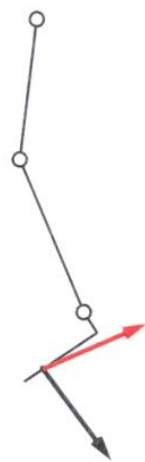

(a) $0 \%$

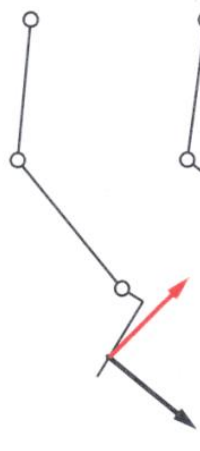

(b) $20 \%$

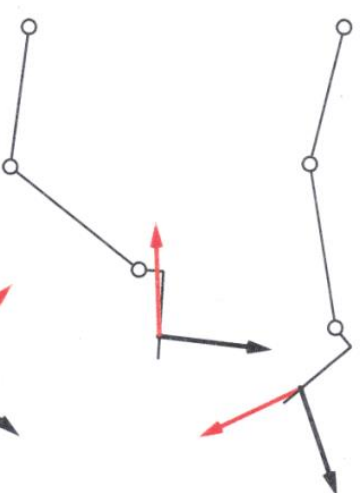

(c) $40 \%$

(d) $60 \%$

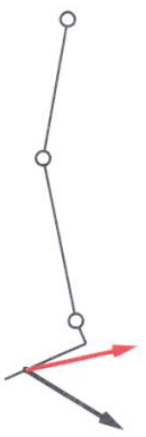

(e) $80 \%$

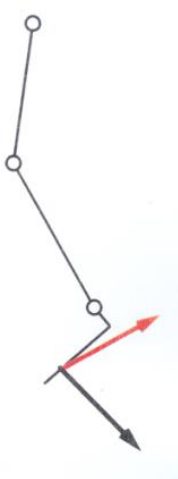

(f) $100 \%$

Fig. 23 The configuration of the human leg motion using the motion transformer (Type I). The black arrow indicates the direction of the pedaling force. The red arrow indicates the direction of the foot motion. The angle between the pedaling force and the direction of the foot motion is larger when the foot is swung backward. 


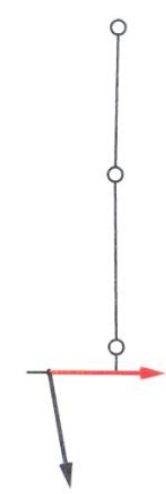

(a) $0 \%$

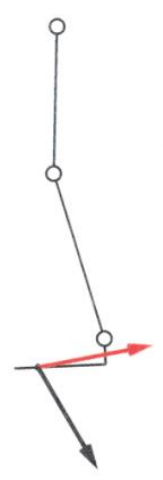

(b) $20 \%$

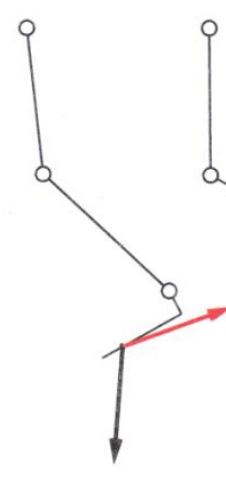

(c) $40 \%$

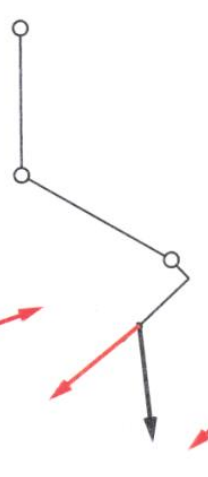

(d) $60 \%$

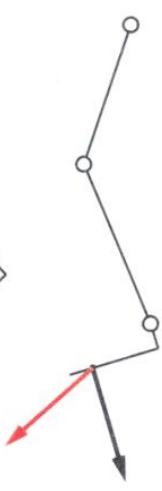

(e) $80 \%$

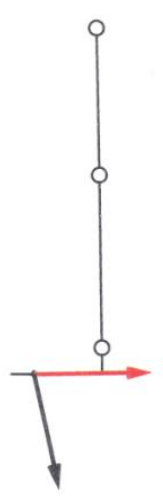

(f) $100 \%$

Fig. 24 The configuration of the human leg motion using the motion transformer (Type II). The black arrow indicates the direction of the pedaling force. The red arrow indicates the direction of the foot motion.

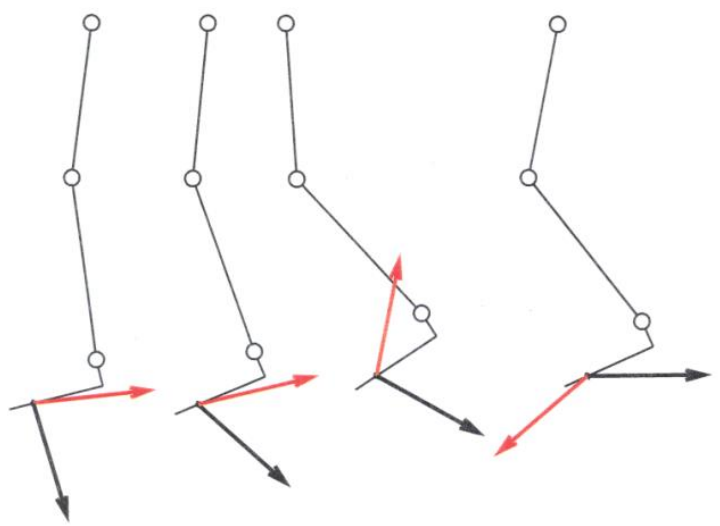

(a) $0 \%$

(b) $20 \%$

(c) $40 \%$

(d) $60 \%$ (e) $80 \%$

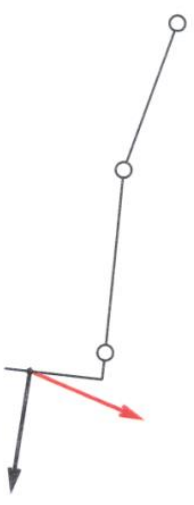

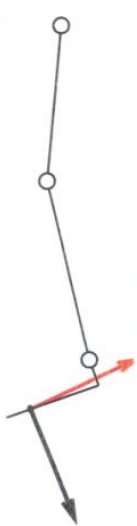

(f) $100 \%$

Fig. 25 The configuration of the human leg motion using the motion transformer (Type III). The black arrow indicates the direction of the pedaling force. The red arrow indicates the direction of the foot motion.

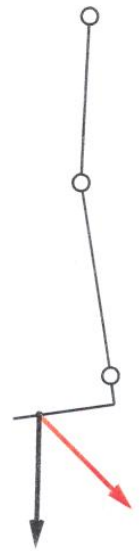

(a) $0 \%$

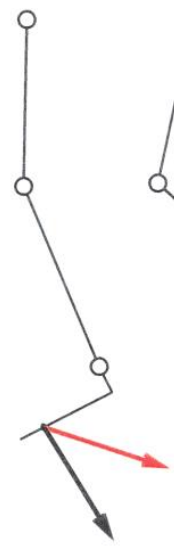

(b) $20 \%$

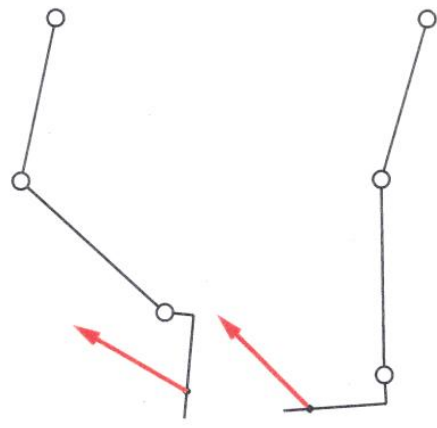

(c) $40 \%$

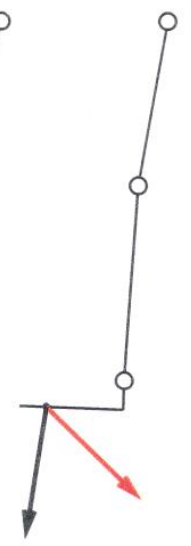

(e) $80 \%$

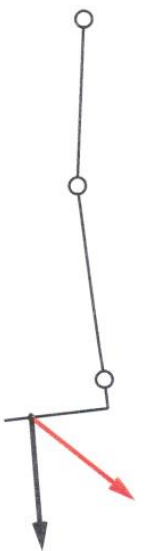

(f) $100 \%$

Fig. 26 The configuration of the human leg normal walking motion. The black arrow indicates the direction of the stepping force against the floor. The red arrow indicates the direction of the foot motion. Because configurations shown in (c) and (d) are in swing phase, the stepping forces against floor don't exist. 


\section{6. 考察}

足関節の描く軌跡を解析によって示した図 14(a)〜(c)より, 回転軸のみで構成された平面 6 節リンク機構を用い た装置（I 形）において，蹴り上げから前方への振り下ろしの動作が，比較的再現できていることがわかる.た だし，この装置の設計において，参照した歩行動作を約 15[deg]右回りに回転させている.これは，最長リンク等 をリンク自重に抗して後方に振り上げることの困難さを回避するためである. スライダを含む平面 6 節リンク機 構を用いた装置（II 形）では，蹴り上げ動作は比較的再現できているのに対し，前方への振り下ろし動作での軌 跡が直線的である．スライダ・クランク機構を用いて前輪を駆動する装置（III 形）では，全体的に軌跡は直線的 となり，膝の可動範囲も小さめである.

このことは, 対応点一組当たりの平均距離からもわかる. 寸なわち, $4 \cdot 3$ 節で示した通り, 回転対偶のみで構 成された装置（I 形）では，対応点一組当たり平均 $31.14\{\mathrm{~mm}\}$ あ゙あたのに対し，スライダを用いた場合である II 形では 48.84\{mm, III 形では 43.85[mm]であった. 歩行動作の軌跡の再現のみを目的とするなら，I 形が適して いることがわかる.

これに対し，試作した装置を実際に駆動した場合，図 16(a)〜(c)を図 14(a)〜(c)と比較すると，図 14(a)では足関 節および拇指関節軌跡とも閉曲線を描いていたものが，図 16(a)では一本の曲線のようになっており，脚部の前後 の摇動においてほぼ同じ軌道を描くようになっていることがわかる. II 形および III 形における足関節の軌跡にお いても，図 14 および図 16 の比較から同様の傾向はあるが，I 形と比較すれば，解析時の運動状況を製作した装 置でも再現できていることがわかる．また，III 形では，解析時には足関節での回転運動を考慮していないが，製 作した装置は，図 16(b)および(c)との比較から，II 形に比較すると，ペダルを操作するために足部が前方にある位 置において足関節を大きく動かしており，参照した歩行動作とは異なる運動となっている．機構の摇動の端点に ある運動限界位置を通過するために，脚部の運動が通常の歩行動作と異なるものとなっていることが考える.

また，設計の際に参照したデータが，I 形では，特定の 1 名分のみを採取したものであり，体格差の影響を大 きく受けると考えられる.

この機構の運動限界位置は，足部が前方に振り出すときと後方一蹴り上げるときの 2 つ存在する. これらの通 過に関しては，出力軸にあるクランクを，リンクの自重に抗して持ち上げなければならないため，脚部を後方に 蹴り上げるときでの通過が困難となる. ただ，左右に位相差が $\pi$ だけ異なるクランクが計 2 つ存在するために, 運動限界位置の通過が不可能な状況にはない.

図 17，18 および 19 にはそれぞれ，I 形，II 形および III 形を使用した際の脚部の各関節角変位の測定值を，4・ 2 節の手法で得られる解析值および設計に用いた参照值とともに示している. 図 17(a)において, 股関節角変位の 測定值は，解析值および参照值のいずれに対しても変動幅が小さくなっている．これは測定装置にポテンショメ 一タを用いた人体への接触形を用いている影響もあるが, Link 1 の静止対偶点がサドル近くにあるため (図 15(a) 参照), 大腿部と Link 1 とが干渉しているためと考えられる。.また，図 17(b)および図 17(c)より，膝関節角変位 および足関節角変位の測定值は，参照值等に比へ，最大值はほぼ同等の值となっているが，全体的に高い值を示 していることがわかる.

また，図 18 より，II 形の使用時では参照值での関節角変位の急激な変化特性は，測定值等では十分に再現でき ていないことがわかる．同様のことは，III 形の使用時についてもいえることが，図 19 からわかる. 特に III 形で は，足関節での回転運動を拘束していないため，測定值と参照值との差が大きい区間が存在する.

ペダル踏力については，図 21(a)〜(d)に示す通り，最大值については，I形および II 形には，大きな違いはない ものの，足関節の回転運動を拘束しない II （足部拘束なし）形およびIII 形等では，これらの值に対し 1/3 程度と なった．これは，使用者が足裏の角度を自由に可動できることで，踏力の向きを出力節のクランクを効果的に回 転させる向きにしているためと思われる。これは，足部の向きも含めた厳密な歩行動作の再現と装置の駆動に関 して相容れない部分が現状において存在することを示している. 歩行動作を誘導する一方で使用者を特定の動作 に限定しない圥長性を機構に与えることを検討することは, 装置を容易に駆動するためだけではなく, 体格差や 歩容の変化に対応寸るためにも今後, 必要になると考えられる. また, 図 22 から, 通常の歩行では遊脚相として 足裏に負荷が作用しない状態であっても駆動には踏力を要していることがわかる. 
図 23〜図 25 には，装置使用時の脚部姿勢とそのときのペダル踏力の向きおよび拇指関節付近の速度の向きを 測定結果から差分で得た值を使用し矢印（赤）で示している。これらの図において，足部の運動方向と踏力の向 きはいずれも異なっている. (a) (c) は支持脚相から遊脚相に, (d) ( f $)$ は遊脚相から支持脚相に切替わる区間をお およそ示している. I〜III 形のいずれにおいても，遊脚時の後方へ最も大きく蹴り上げる 40〜60\%付近において 踏力と運動方向が大きく異なっており，効果的な装置の駆動が困難であることがわかる.

また，図 26 において(c)および(d)は，遊脚相であるため，踏力は存在しないが，その他では，拇指関節付近の 速度と踏力の向きが互いに鋭角をなしていることがわかる.

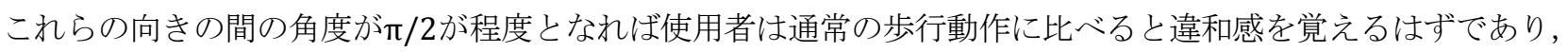
必要な踏力が小さくとも使いにくさを感じる原因になると考えられる.

歩行時の脚部動作の再現に関しては一定の目途がついたものの, 遊脚でもペダル踏力が必要になるなど歩行位 相に関する情報の提示は十分再現されておらず，今後の課題となる.

さらに, 自走式以外での運動変換機構, 例えば歩行時の脚部動作の連動した運動感覚を取得する装置等への応 用についても検討寸る予定である.

\section{7. 結言}

本研究では, 乗用型歩行訓練器に用いる疑似歩行動作 - 回転運動変換機構の設計手法を示し, 試作した装置に おいて，使用時の人体脚部動作や駆動に必要な踏力の測定を行った．以上，得られた結果を要約すると以下のよ うになる。

(1) 平面 4 節リンク機構の中間節上の点で, 歩行時の足関節の描く軌跡を追従する機構の設計手法を示した.

(2) (1) の平面 4 節リンク機構にさらに 2 リンク追加し, 歩行時の足裏部を案内するワット形平面 6 節リンク機構 の設計手法を示した. さらに, この平面 4 節リン機構の回転対偶のうちのひとつを直進対偶として疑似歩行動作 一回転運動変換機構の設計も行った.

(3) (1)および(2)の機構を実際に試作し, それらについて使用時の脚部動作と駆動に必要なペダル踏力の測定を行 った.

(4) 疑似的な歩行動作を再現するためには, すべてのリンクを回転対偶で連結した機構において実現の可能性が 高いことを示した.ただし, 試作した装置を実際に駆動する際の脚部動作は, 駆動に必要な踏力が大きいことが 影響し，歩行動作時のそれとは異なる.

(5) スライダを用いた機構では, 足部の軌跡はやや直線的になるものの, シミュレーションで得られた脚部動作 を, 試作した装置を実際に駆動した際にもほぼ再現できることが確認できた.

（6）足関節での回転運動を拘束しない機構において，駆動に要するペダル踏力は小さくできることを確認した.

(7) 装置使用時のペダル踏力の向きは, 遊脚時の後方への蹴り上げが最大となる姿勢で, 足部の運動と大きく異 なり，通常歩行時の感覚を使用者に提供するには，現在の状態は決して十分ではない，

また，この種の機構を福祉分野へ応用した際の使用者のリハビリへの意欲増進等の効果を確認するためには， 表面筋電位による人体の負担や官能試験等が不可欠である. これらの臨床的な試験に関しては，今後の課題とな る.

\section{文献}

赤木 徹也, 堂田 周治郎, 趙 菲菲, 藤田 圭司, 内径センサ内蔵型ゴム人工筋の開発と制御, 日本機械学会論文 集 C 編, Vol. 77, No. 779 (2011), pp. 2711-2719.

安藤健, 大木英一, 中島康貴, 秋田裕, 飯島浩, 田中理, 藤江正克, 左右分離型トレッドミルを用いた歩行相フ ィードバックシステム，日本機械学会論文集 C 編，Vol. 77, No. 783 (2011), pp. 4189-4203.

安藤健, 山田憲嗣, 清水佐知子, 大野ゆう子, 電動ベッドに後付け可能な起立支援機器の提案, 日本機械学会論 文集 C 編, Vol. 78, No. 785 (2012), pp. 151-162. 
Garrett, R.E. and Hall Jr, A. S, Optimal synthesis of randomly generated linkages, Transactions of the ASME, Journal of Engineering for Industry, Vol. 90, No. 3 (1968), pp. 475-480.

Gopura, R.A. R. C. and Kiguchi, K., An exoskeleton robot for human forearm and wrist motion assist -Hardware design and EMG-based controller, Journal of Advanced Mechanical Design, Systems, and Manufacturing, Vol. 2, No. 6 (2008), pp. 1067-1083.

原 進, 湯地 恒太, 吉浦 隆仁, 山田 陽滋, 意図しない入力による搬送物への影響を考慮したパワーアシストシ ステムの制御系設計，日本機械学会論文集 C 編，Vol. 78, No. 793 (2012), pp. 3279-3283.

初雁 卓郎, 三宅 徳久, 平田 泰久, 小菅一弘, 人体モデルを用いた起立分類に基づく起立支援デバイスの選定 手法，日本機械学会論文集 C 編，Vol. 77, No. 774 (2011),pp. 429-438.

林 知広, 岩月 幸一, 山海 嘉之, 神経・筋活動の制御に支障がある重度対麻痺患者の脚上げ意思推定と歩行アシ スト，日本機械学会論文集 C 編，Vol. 77, No. 774 (2011), pp. 439-449.

林 良太，須川 誠也，衛藤 誠二，野間 知一，余 永，下堂薗 恵，川平 和美，他動運動による肘関節における筋 緊張異常検査システムの開発，日本機械学会論文集 C 編，Vol. 78, 796 (2012), pp. 3936-3946.

株式会社 日立製作所，News Release <http://www.hitachi.co.jp/New/cnews/9905/0524b.html>，

(参照日 2013 年 12 月 28 日).

稲葉 智也, 則次 俊郎, 二関節筋型ゴム人工筀を用いた支援装置モデルの解析と制御, 日本機械学会論文集 C 編, Vol. 77, No. 778 (2011), pp. 2323-2335.

インターリハ株式会社，トレッドミル ロボウォーク・エキスパンダー <http://www.irc-web.co.jp/treadmill_robowalk_expander/>, (参照日 2013 年 12 月 28 日).

池原 忠明, 田中 英一郎, 永村 和照, 牛田 卓朗, 小島 翔, 田宮 高信, 池条 清隆, 青景 遵之, 中川 慧, 弓削 類, フレキシブルシャフトのねじりばね効果を用いた脚部密着型歩行補助機の開発, 日本機械学会論文集 C 編, Vol. 77, No. 775 (2011), pp. 698-711.

Kai, Y., Development of a walking support machine with mechanical safety devices, Proceedings of The 4th International Conference on Manufacturing, Machine Design and Tribology (ICMDT 2011), pp. 99-100.

河内 まき子, 持丸正明, AIST 人体寸法データベース 1991-92, 独立行政法人産業技術総合研究所著作物, 管理番号 H16PRO 287, <https://www.dh.aist.go.jp/database/91-92/data/list.html>, (参照日 2013 年 12 月 28 日).

中島康貴, 安藤健, 小林洋, 二瓶美里, 藤江正克, 平地のように加減速歩行が可能なトレッドミルの制御手法の 開発，バイオメカニズム(2012), pp.191-200(in Japanese).

裴 艶玲, 金 泳佑, 大日方 五郎, 元田 英一, 長谷 和徳, 生体力学的安全性を考慮した 3 次元下肢リハビリテ ーション軌道と足先作用力の同時設計手法, 日本機械学会論文集 C 編, Vol. 78, No. 792 (2012), pp. $2972-2986$.

裴 艶玲, 金 泳佑, 大日方 五郎, 長谷 和徳, ロボット支援型下肢リハビリテーションにおける筋骨格モデルに 基づいた運動軌道と足先に作用する力の設計, 日本機械学会論文集 C 編, Vol. 77, No. 781 (2011), pp. 3439-3453.

佐藤 裕, 何 佳欧, 小林 寛征, 村松 慶紀, 橋本 卓弥, 小林 宏, 腰補助用マッスルスーツの開発と定量的評 価，日本機械学会論文集 C 編，Vol. 78, No. 792 (2012), pp. 2987-2999.

新宮正弘, 江口清, 山海嘉之, バイオフィードバックを用いたポリオ経験者の筋神経系制御能力の改善とロボッ トスーツ HAL による麻痺肢動作支援，日本機械学会誌 C 編，Vol. 76，No. 772 (2010), pp. 3630-3639.

田中英一郎, 池原 忠明, 船山 和也, 紺谷真紀人, 初雁 卓郎, 三宅 徳久, 仰臥位へ変形可能な体幹前傾式起立 補助機の機構設計，日本機械学会論文集 C 編, Vol. 77, No. 775 (2011a), pp. 712-727. 
田中英一郎，池原忠明，佐藤友亮，遊佐広和，伊藤和寿，三枝省三，中川 慧，青景遵之，弓削 類，脚部非固定 式歩行補助機の開発と筋電による補助効果の検討，日本機械学会論文集 C 編，Vol. 77, No. 775 (2011b), pp. 1119-1132.

Tanaka, E., Saegusa, S. and Yuge, L., Development of a whole body motion support type mobile suit and evaluation of cerebral activity corresponding to the cortical motor areas, Journal of Advanced Mechanical Design, Systems, and Manufacturing, Vol. 7, No. 1 (2013), pp. 82-94.

渡辺 克己, 林 寿雄, 南後 淳, 最小二乗法による曲線照合, 日本機械学会論文集 C 編, Vol. 61, No. 591(1995), pp. 4529-4535.

Wu, Y., Nakamura, H., Takeda, Y., Higuchi, M. and Sugimoto, K., Development of a power assist system of a walking chair based on human arm characteristics, Journal of Advanced Mechanical Design, Systems, and Manufacturing, Vol. 1, No. 1 (2007), pp. 141-154.

山田 泰之, 森田 寿郎, 歩行時の垂直方向の動摇から上体の位置エネルギを回生する歩行アシスト装置の機構開 発, 日本機械学会論文集 C 編, Vol. 79, No. 802 (2013), pp. 2025-2036.

柳原 聖, 龍 勝之, 三原徳馬, 土屋健介, 発電機構を利用した高齢者向け筋力測定およびトレーニング装置の開 発, 日本機械学会論文集 C 編, Vol. 77, No. 776 (2011), pp. 1404-1412.

許 瑛, 渡辺 克巳, 加藤 宏章, 曲線照合法による非グラスホフ平面 4 節リンク機構のカップラーカーブの探索, 日本機械学会論文集 C編，Vol. 67, No. 658(2001), pp. 1965-1972.

Zhu, Y., Nakamura, M., Ito, N., Fujimoto, H., Horikuchi, K., Wakabayashi, S., Takahashi, R., Terada, H. and Haro, H., Study of wearable knee assistive instruments for walk rehabilitation, Journal of Advanced Mechanical Design, Systems, and Manufacturing, Vol. 6, No. 2 (2012), pp. 260-273.

\section{References}

Akagi, T., Dohta, S., Zhao, F. and Fujita, K., Development of a rubber artificial muscle with inner diameter sensor and its control, Transactions of the Japan Society of Mechanical Engineers, Series C, Vol. 77, No. 779 (2011), pp. 2711-2719 (in Japanese).

Ando, T., Ohki, E., Nakashima, Y., Akita, Y., Iijima, H., Tanaka, O. and Fujie, M. G., Visual bio-feedback system of gait phase in split belt treadmill, Transactions of the Japan Society of Mechanical Engineers, Series C, Vol. 77, No. 783 (2011), pp. 4189-4203 (in Japanese).

Ando, T., Yamada, K., Shimizu, S. and Ohno, Y., An attachable standing-assist-robot to motorized bed, Transactions of the Japan Society of Mechanical Engineers, Series C, Vol. 78, No. 785 (2012), pp. 151-162 (in Japanese).

Garrett, R.E. and Hall Jr, A. S, Optimal synthesis of randomly generated linkages, Transactions of the ASME, Journal of Engineering for Industry, Vol. 90, No. 3 (1968), pp. 475-480.

Gopura, R.A. R. C. and Kiguchi, K., An exoskeleton robot for human forearm and wrist motion assist -Hardware design and EMG-based controller, Journal of Advanced Mechanical Design, Systems, and Manufacturing, Vol. 2, No. 6(2008), pp. 1067-1083.

Hara, S., Yuchi, K., Yoshiura, T. and Yamada, Y., Controller design of power assist systems taking account of influence to conveyed objects by unintentional input force, Transactions of the Japan Society of Mechanical Engineers, Series C, Vol. 78, No. 793 (2012), pp. 3279-3283 (in Japanese). 
Hatsukari, T., Miyake, N., Hirata, Y. and Kosuge, K., Method for selecting standing-up assist devices based on standing-up classification with human model, Transactions of the Japan Society of Mechanical Engineers, Series C, Vol. 77, No. 774 (2011), pp. 429-438 (in Japanese).

Hayashi, T., Iwatsuki, K. and Sankai, Y., Intention estimation and walking assistance for severe paraplegic patients having difficulty in controlling neuromuscular activity, Transactions of the Japan Society of Mechanical Engineers, Series C, Vol. 77, No. 774 (2011), pp. 439-449 (in Japanese).

Hayashi, R., Sugawa, S., Etoh, S., Noma, T., Yu, Y., Shimodozono, M. and Kawahira, K., Development of the inspection system for myotonic symptoms in the elbow during passive motion, Transactions of the Japan Society of Mechanical Engineers, Series C, Vol. 78, 796 (2012), pp. 3936-3946 (in Japanese).

Hitachi, Ltd, News Release, available from<http://www.hitachi.co.jp/New/cnews/9905/0524b.html>, (accessed on 28 December, 2013) (in Japanese).

Inaba, T. and Noritsugu, T., Analysis and control of model to develop support device using biarticular muscle with rubber artificial muscles, Transactions of the Japan Society of Mechanical Engineers, Series C, Vol. 77, No. 778 (2011), pp. 2323-2335 (in Japanese).

Inter-Riha Co.,Ltd, Treadmill robowalk expander, available from <http://www.irc-web.co.jp/treadmill_robowalk_expander/>, (accessed on 28 December, 2013) (in Japanese).

Ikehara, T., Tanaka, E., Nagamura, K., Ushida, T., Kojima, S., Tamiya, T., Ikejyo, K., Aokage, Y., Nakagawa, K. and Yuge, L., Development of a closed-fitting-type walking assistance device on leg using torsion spring effect of a flexible shaft, Transactions of the Japan Society of Mechanical Engineers, Series C, Vol. 77, No. 775 (2011), pp. 698-711 (in Japanese).

Kai, Y., Development of a walking support machine with mechanical safety Devices, Proceedings of The 4th International Conference on Manufacturing, Machine Design and Tribology (ICMDT 2011), pp. 99-100.

Kouchi, M., Mochimaru, M., The National Institute of Advanced Industrial Science and Technology (AIST) Data Base, Copyright 2001-2003, Digital Human Laboratory, AIST, Copyright 2003-2012, Digital Human Research Center, AIST, H16PRO 287, available from <https://www.dh.aist.go.jp/database/91-92/data/list.html>, (accessed on 28 December, 2013) (in Japanese).

Nakashima, Y., Ando, T., Kobayashi, Y., Nihei, M. and Fujie, M. G., Treadmill control for simulated acceleration and deceleration during overground walking, Biomechanisms(2012), pp.191-200(in Japanese).

Pei, Y., Kim, Y., Obinata, G., Genda, E. and Hase, K., Simultaneous design of 3D lower limb rehabilitation trajectory and external force in consideration of biomechanical stability, Transactions of the Japan Society of Mechanical Engineers, Series C, Vol. 78, No. 792 (2012), pp. 2972-2986 (in Japanese).

Pei, Y., Kim, Y., Obinata, G. and Hase, K., Design of motion trajectory and external force on foot based on musculo-skeletal model in robot-assisted lower limb rehabilitation, Transactions of the Japan Society of Mechanical Engineers, Series C, Vol. 77, No. 781 (2011), pp. 3439-3453 (in Japanese).

Sato, Y., He, J., Kobayashi, H., Muramatsu, Y., Hashimoto, T. and Kobayashi, H., Development and quantitative performance estimation of the back support muscle suit, Transactions of the Japan Society of Mechanical Engineers, Series C, Vol. 78, No. 792 (2012), pp. 2987-2999 (in Japanese).

Shingu, M., Sankai, Y., Neuromuscular system improvement and movement assistance of polio survivor with paralysis using biofeedback and robot suit HAL, Transactions of the Japan Society of Mechanical Engineers, Series C, Vol. 76, No. 772 (2010), pp. 3630-3639 (in Japanese). 
Tanaka, E., Ikehara, T., Funayama, K., Kontani, M., Hatsukari, T. and Miyake, N., Mechanical design of a standing up assistance apparatus of leaning forward the upper body which can be transformed into a flat lying posture, Transactions of the Japan Society of Mechanical Engineers, Series C, Vol. 77, No. 775 (2011a), pp. $712-727$ (in Japanese).

Tanaka, E., Ikehara, T., Sato, Y., Yusa, H., Ito, K., Saegusa, S., Nakagawa, K., Aokage, Y. and Yuge, L., Development of a walking assistance apparatus without fixation on legs and study on the assistance effectiveness with electromyography, Transactions of the Japan Society of Mechanical Engineers, Series C, Vol. 77, No. 775 (2011b), pp. 1119-1132 (in Japanese).

Tanaka, E., Saegusa, S. and Yuge, L., Development of a whole body motion support type mobile suit and evaluation of cerebral activity corresponding to the cortical motor areas, Journal of Advanced Mechanical Design, Systems, and Manufacturing, Vol. 7, No. 1(2013), pp. 82-94.

Watanabe, K., Hayashi, H. and Nango, J., Comparison of two curves by means of least squares method, Transactions of the Japan Society of Mechanical Engineers, Series C, Vol. 61, No. 591 (1995), pp. 4529-4535 (in Japanese).

Wu, Y., Nakamura, H., Takeda, Y., Higuchi, M. and Sugimoto, K., Development of a power assist system of a walking chair based on human arm characteristics, Journal of Advanced Mechanical Design, Systems, and Manufacturing, Vol. 1, No. 1(2007), pp. 141-154.

Yamada, Y. and Morita, T., Development of walking assist device by regenerating the upper body position energy from vertical oscillation of the upper body, Transactions of the Japan Society of Mechanical Engineers, Series C, Vol. 79, No. 802 (2013), pp. 2025-2036 (in Japanese).

Yanagihara, K., Ryu, K., Mihara, T. and Tsuchiya, K., Development of measuring and training system by using electric dynamometer for old age people, Transactions of the Japan Society of Mechanical Engineers, Series C, Vol. 77, No. 776 (2011), pp. 1404-1412 (in Japanese).

Ying, X., Watanabe, K. and Katoh, H., Synthesis of coupler curves of nongrash of planar four-link mechanisms by a pattern matching method, Transactions of the Japan Society of Mechanical Engineers, Series C, Vol. 67, No. 658 (2001), pp. 1965-1972 (in Japanese).

Zhu, Y., Nakamura, M., Ito, N., Fujimoto, H., Horikuchi, K., Wakabayashi, S., Takahashi, R., Terada, H. and Haro, H., Study of wearable knee assistive instruments for walk rehabilitation, Journal of Advanced Mechanical Design, Systems, and Manufacturing, Vol. 6, No. 2(2012), pp. 260-273. 